\title{
CRÓNICA DE JURISPRUDENCIA NACIONAL DE DERECHO PROCESAL: PRIMER SEMESTRE DE 2017
}

\author{
Bárbara SÁNCHEZ LÓPEZ \\ Departamento de Derecho Procesal \\ Facultad de Derecho. Universidad Complutense de Madrid \\ basanche@der.ucm.es
}

\section{TRIBUNAL CONSTITUCIONAL}

STC (Sala 2. ${ }^{a}$ ) núm. 3/2017, de 16 de enero (rec. 3398/2015), y STC (Sala 1. ${ }^{a}$ ) núm. 4/2017, de 16 de enero (rec. 4033/2015): vulneración del derecho a la tutela judicial efectiva en su vertiente de derecho de acceso, por suspensión y posterior archivo de proceso individual de nulidad de cláusulas abusivas a causa del ejercicio de una acción colectiva de cesación.

STC (Sala 1. ${ }^{a}$ ) núm. 5/2017, de 16 de enero (rec. 4591/2015), y STC (Sala 2. ${ }^{a}$ ) núm. 6/2017, de 16 de enero (rec. 1881/2016): vulneración del derecho a la tutela judicial sin indefensión a causa del emplazamiento edictal del ejecutado en proceso de ejecución hipotecaria pese a la constancia de domicilio extrarregistral.

STC (Pleno) núm. 8/2017, de 19 de enero (rec. 2341/2012), y STC (Sala 2. ${ }^{a}$ ) núm. 10/2017, de 30 de enero (rec. 7088/2012): vulneración del derecho a la presunción de inocencia por denegación de indemnización por prisión provisional fundada en la inexistencia objetiva del hecho punible por dudas sobre los hechos típicos. Existencia de votos particulares.

STC (Sala 2. ${ }^{a}$ ) núm. 12/2017, de 30 de enero (rec. 4090/2014): vulneración del derecho de acceso a la jurisdicción por la apreciación tardía y sin dar oportunidad previa de subsanar la falta de requisitos para entablar acciones por personas jurídicas que la demandante intentó subsanar temporáneamente.

STC (Sala 2. ${ }^{a}$ ) núm. 13/2017, de 30 de enero (rec. 7301/2014): vulneración de los derechos a la libertad personal y a la asistencia letrada del detenido por la negativa a proporcionar copia del atestado policial al letrado. 
STC (Sala 2. ${ }^{a}$ ) núm. 14/2017, de 30 de enero (rec. 1920/2015), y STC (Sala 1. ${ }^{a}$ ) núm. 29/2017, de 27 de febrero (rec. 3279/2014): necesidad de ponderar las circunstancias personales y familiares del extranjero condenado por delito doloso antes de acordar su expulsión de territorio nacional.

STC (Pleno) núm. 15/2017, de 2 de febrero (rec. inconst. 1024/2013); STC (Pleno) núm. 35/2017, de 1 de marzo (rec. inconst. 3076/2013), y STC (Pleno) núm. 35/2017, de 1 de marzo (rec. inconst. 5046/2016): pérdida sobrevenida de objeto de recurso de inconstitucionalidad contra diversos preceptos relativos a las tasas judiciales de la Ley 10/2012, de 20 de noviembre.

STC (Sala 2. ${ }^{a}$ ) núm. 22/2017, de 13 de febrero (rec. 5046/2015): vulneración del derecho a la tutela judicial efectiva por no aplicar la jurisprudencia del TC sobre la inidoneidad de la querella para interrumpir por sí sola la prescripción penal.

STC (Sala 2. ${ }^{a}$ ) núm. 30/2017, de 27 de febrero (rec. 22/2015): vulneración del derecho a la tutela judicial efectiva en relación con el derecho a una resolución motivada sobre la revisión de sentencias contencioso-administrativas firmes basada en la inconstitucionalidad sobrevenida de la ley aplicada.

STC (Sala 1. ${ }^{a}$ ) núm. 39/2017, de 24 de abril (rec. 332/2016): vulneración del derecho a la tutela judicial efectiva en relación con el derecho a la integridad física y moral, por no haberse agotado todas las vías de investigación en una causa de malos tratos a un detenido en situación de incomunicación.

STC (Sala 1. ${ }^{a}$ ) núm. 41/2017, de 24 de abril (rec. inconst. 5077/2016): inconstitucionalidad, por vulneración del derecho a una resolución sobre el fondo, del precepto foral navarro que impide a los progenitores la reclamación de la filiación no matrimonial.

STC (Sala 2. ${ }^{a}$ ) núm. 40/2017, de 24 de abril (rec. 351/2016): extensión de los efectos retroactivos de la nulidad, por inconstitucionalidad, de la Ley 10/2012, de Tasas Judiciales, a procesos en los que el pago haya obstaculizado el acceso al recurso.

\section{TRIBUNAL SUPREMO: SALA $1 .{ }^{a} \mathrm{O}$ DE LO CIVIL}

STS (Sala 1.a) núm. 1/2017, de 10 de enero (rec. 944/20014): incompetencia de los tribunales españoles a causa de forum shopping artificialmente provocado mediante una acumulación subjetiva de acciones para sustraer al principal demandado de su foro de defensa. 
ATS (Sala 1. ${ }^{a}$ ) de 8 de febrero de 2017 (rec. 1752/2014): suspensión de recurso de casación interpuesto por el banco predisponente y planteamiento de cuestión prejudicial comunitaria al TJUE en relación con el alcance de la nulidad contractual de vencimiento anticipado a causa del impago de una sola cuota de amortización mensual.

ATS (Sala 1. ${ }^{a}$ en Pleno) de 15 de febrero de 2017 (rec. 1085/2016) y ATS (Sala 1. ${ }^{\text {a }}$ ) de 29 de marzo de 2017 (rec. 5/2017): conflicto negativo de competencia resuelto a favor del Juzgado de Violencia sobre la Mujer por la pendencia de proceso penal al tiempo de interposición de la demanda civil en virtud de la perpetuatio iurisdictionis, aunque después se acordara el archivo o el sobreseimiento.

STS (Sala 1. en Pleno) núm. 23/2017, de 24 de febrero (rec. 740/2014), y STS (Sala 1. a) núm. 345/2017, de 1 de junio (rec. 393/2015): aplicación de la nueva doctrina del TS sobre la devolución de las cantidades indebidamente cobradas en virtud de una cláusula suelo declarada nula, más sus intereses legales.

STS (Sala 1.a) núm. 157/2017, de 7 de marzo (rec. 1874/2016): nulidad de la sentencia de apelación en la que se revoca el régimen de guarda y custodia del hijo menor por no haber sido explorado.

ATS (Sala 1. ${ }^{a}$ ) de 15 de marzo de 2017 (rec. 329/2013): los tribunales nacionales no tienen facultades moderadoras de los derechos arancelarios de procurador, pese a que se impugne su tasación por incompatibilidad con el Derecho europeo.

ATS (Sala 1. ${ }^{a}$ en Pleno) de 4 de abril de 2017 (rec. 7/2017), ATS (Sala 1. ${ }^{a}$ ) de 19 de abril de 2017 (rec. 12/2017) y ATS (Sala 1. ${ }^{a}$ ) de 10 de mayo de 2017 (rec. 25/2017): no cabe revisar una sentencia firme a causa de un cambio de la jurisprudencia posterior, pese a que el cambio venga propiciado por una sentencia del TJUE.

STS (Sala 1. ${ }^{a}$ ) núm. 222/2017, de 5 de abril (rec. 542/2015): legitimación activa de la tomadora de seguro de vida e incapacidad permanente absoluta para exigir el cumplimiento del contrato del que es beneficiaria la entidad bancaria que predispuso su contratación vinculada con un préstamo hipotecario.

STS (Sala 1. a) núm. 251/2017, de 25 de abril (rec. 2981/2017): validez de una cláusula de venta extrajudicial de bien hipotecado por no producir por sí misma desequilibrio contractual al no haberse alegado la existencia de cláusulas materiales abusivas.

STS (Sala 1.a) núm. 320/2017, de 23 de mayo (rec. 837/2015): constitucionalidad y validez del procedimiento no jurisdiccional de venta extrajudicial por suficiencia del rango legal prestado por la LEC. 
STS (Sala 1. a en Pleno) núm. 324/2017, de 24 de mayo (rec. 197/2015): subsistencia de la capacidad para ser parte y procesal de sociedad disuelta y liquidada a los efectos del reconocimiento judicial de deudas sobrevenidas.

STS (Sala 1.a) núm. 336/2017, de 29 de mayo (rec. 483/2015): inexistencia de responsabilidad civil del procurador por la caducidad de una anotación preventiva de embargo a causa de no tener obligación de cuidado.

\section{TRIBUNAL SUPREMO: SALA 2. ${ }^{a}$ O DE LO PENAL}

STS (Sala 2.a) núm. 28/2017, de 25 de enero (rec. 949/2016): ni se puede ni se debe aplicar la «tesis del tribunal» para condenar por un título penal aplicable a un relato histórico no equiparable al que fue objeto de acusación.

STS (Sala 2. ${ }^{a}$ ) núm. 93/2017, de 16 de febrero (rec. 617/2016): no pierde la imparcialidad el juez que enjuicia al mismo acusado en causas distintas.

STS (Sala 2. ${ }^{a}$ ) núm. 95/2017, de 16 de febrero (rec. 10574/16): improcedencia de acumular penas impuestas en otro Estado UE en los supuestos del art. 14.2 de la LO 7/2014 y su conformidad con la Decisión Marco 2208/675.

STS (Sala 2. ${ }^{a}$ ) núm. 116/2017, de 23 de febrero (rec. 1281/2016): condena por delito fiscal basada en datos provenientes de la «lista Falciani»: licitud del uso de la información financiera sustraída por un informático del banco, intervenida por las autoridades francesas y remitida a la AEAT mediante solicitud de cooperación internacional.

STS (Sala 2. ${ }^{a}$ ) núm. 156/2017, de 13 de marzo (rec. 1304/2016): vulneración del derecho a la presunción de inocencia: improcedente condena basada en declaraciones sumariales de coacusados que se acogieron al derecho a no declarar contra sí mismos.

STS (Sala 2. ${ }^{\circ}$ ) núm. 226/2017, de 31 de marzo (rec. 1825/2016): recurso de casación contra auto de sobreseimiento libre dictado por la audiencia provincial en procedimiento abreviado pese a la interposición previa de recurso de súplica por error en la instrucción de los recursos.

STS (Sala 2. ${ }^{a}$ ) núm. 287/2017, de 19 de abril (rec. 1893/2016): validez probatoria de fotografías de abusos sexuales de un padre a su hija facilitadas por la madre en una memoria flash procedentes de ordenador portátil de uso compartido.

STS (Sala 2.`) núm. 291/2017, de 24 de abril (rec. 1662/2016): criterios para la imposición de la condena en costas a la acusación particular en el supuesto de desistimiento de la acusación: concepto de temeridad y mala fe. 
STS (Sala 2. ${ }^{a}$ ) núm. 329/2017, de 9 de mayo (rec. 10748/2016): prueba indiciaria condenatoria en tribunal del jurado.

\section{SELECCIÓN DE OTRAS RESOLUCIONES Y ACTOS EN MATERIA PROCESAL}

AAP Murcia (Secc. 2. ${ }^{a}$, constituida con el pleno de los magistrados del orden penal) de 9 de enero de 2017 (rec. 295/2016), sobre fijación de criterio común relativo al carácter jurisdiccional e indelegable de la decisión sobre la solicitud de trascripción de declaraciones sumariales grabadas en vídeo.

Acuerdo del Pleno no jurisdiccional de la Sala de lo Civil del Tribunal Supremo de fecha 27 de enero de 2017, sobre criterios de admisión de los recursos de casación y extraordinario por infracción procesal.

Acuerdo no jurisdiccional de unificación de criterios de magistrados pertenecientes a las secciones civil y mercantil de la Audiencia Provincial de Madrid de fecha 14 de febrero de 2017.

Acuerdo de pleno jurisdiccional civil de la Audiencia Provincial de Murcia de fecha 17 de febrero de 2017 para unificar criterios en las secciones civiles en relación con los procedimientos de ejecución hipotecaria en los que se discuta la validez de la cláusula de vencimiento anticipado.

RDGRN de 24 de marzo de 2017, por la que se revoca la calificación negativa del registrador que suspendió la inscripción de un decreto de adjudicación dictado en proceso de ejecución hipotecaria a causa de existir, según el título, ocupantes a los que no consta que se les hubiera notificado la transmisión de la finca ex art. 25 LAU: inoponibilidad, desde la Ley $4 / 2013$, de 4 de junio, del arrendamiento no inscrito frente a tercer adquirente.

Instrucción 1/2017, de 27 de marzo, de la Fiscalía General del Estado, sobre la actuación del fiscal para la protección de los derechos al honor, intimidad y propia imagen de menores de edad con discapacidad ante los medios de comunicación audiovisual.

Instrucción 2/2017, de 28 de abril, de la Fiscalía General del Estado, sobre procesos incoados a raíz de la deducción de testimonios de una causa principal.

Dictamen 1/2017, de 19 de mayo, de la Fiscal de Sala de Cooperación Internacional, sobre el régimen legal aplicable debido a la no trasposición en plazo de la directiva de la orden europea de investigación y sobre el sig- 
nificado de la expresión «disposiciones correspondientes» que sustituye dicha directiva.

Acuerdo (2.20) de la Comisión Permanente del CGPJ de 25 de mayo de 2017, por el que se acuerda la especialización de 54 juzgados de primera instancia - uno por provincia en la península y uno en cada una de las principales islas de los archipiélagos canario y balear- para conocer de forma exclusiva y no excluyente de los litigios relacionados con las condiciones generales incluidas en contratos de financiación con garantías reales inmobiliarias cuyo prestatario sea una persona física.

\section{TRIBUNAL CONSTITUCIONAL}

STC (Sala 2. ${ }^{a}$ ) núm. 3/2017, de 16 de enero (rec. 3398/2015), y STC (Sala 1. ${ }^{a}$ ) núm. 4/2017, de 16 de enero (rec. 4033/2015): vulneración del derecho a la tutela judicial efectiva en su vertiente de derecho de acceso, por suspensión y posterior archivo de proceso individual de nulidad de cláusulas abusivas a causa del ejercicio de una acción colectiva de cesación

El supuesto de hecho y la solución de estas dos importantes SSTC de la Sala 2. y de la Sala 1. ${ }^{a}$ están en la línea de la STC 148/2016, de 19 de septiembre, precursora de la doctrina que aquí se reafirma, a saber: son contrarios al derecho de acceso a la jurisdicción (art. 24.1 CE) la suspensión y el posterior archivo de un proceso individual de declaración de cláusulas abusivas por causa de prejudicialidad derivada de la existencia de un proceso colectivo de cesación de las mismas cláusulas a instancia de una asociación de consumidores y usuarios.

De la precedente STC 148/2016 se resalta que «"el consumidor individual no necesita estar presente en las actuaciones del proceso colectivo y, por ello mismo, puede actuar al margen de él ejercitando la acción de nulidad individual en un proceso autónomo. También que, en consecuencia, no puede deducirse judicialmente ninguna privación o sacrificio a dicha acción individual, por mor de una carga de personación al proceso de cesación que no existe" [...] "la ley no fija ningún tipo de preterición, sea por la vía de la litispendencia u otra, de las acciones individuales frente a la acción colectiva de cesación, quedando indemne el derecho del interesado para impetrar la tutela autónoma de sus derechos e intereses legítimos de manera separada" [...] "de lo expuesto se deriva que no aparecen 
normas que habiliten al juez para acordar la exclusión o archivo del proceso de nulidad individual por la mera admisión a trámite de una acción de cesación de la misma cláusula, resultando más bien claras las expresiones del legislador en sentido contrario a esa tesis restrictiva del derecho de acceso a la jurisdicción" [STC 148/2016, FJ 4.c)]».

En los dos casos examinados en estas SSTC, la Sala 1. ${ }^{a}$ y la Sala 2. ${ }^{a}$ del TC coinciden en considerar que «las resoluciones aquí impugnadas "prescindiendo del marco normativo propio de las acciones colectivas de cesación al que debía atenderse [...] han denegado la tutela jurisdiccional solicitada a través de la demanda de nulidad individual de cláusula abusiva, remitiendo a los actores a un proceso de cesación iniciado casi dos años antes en un Juzgado de Madrid por una asociación de consumidores [...].

En consecuencia, si los aquí recurrentes no eran parte en ese proceso de acción colectiva ni estamos en un supuesto de legitimación indirecta impuesta ex lege (como en el ámbito de la defensa colectiva de los derechos de propiedad intelectual y las entidades de gestión especializadas: SSTC 196/2009, de 28 de septiembre, FJ 3, y 123/2010, de 29 de noviembre, FJ 3), la conclusión lógica es que falta la identidad del elemento subjetivo necesario entre ambos procesos, el de cesación y el individual, para poder acordar la litispendencia" (FJ 6).

En el aspecto objetivo, por su lado, la identidad entre el proceso individual y el colectivo resulta cuanto menos dudosa, por cuanto, "la demanda de cesación se configura por ley como instrumento de control abstracto de cláusulas ilícitas, y lo que se pretende con ella es que el profesional demandado deje de recomendarlas o suscribirlas con sus potenciales clientes. En este caso, la acción de cesación de ADICAE impugnaba, entre otras, la cláusula suelo cuyo contenido coincide con la firmada por los recurrentes años antes con la misma entidad bancaria. Pero lo cierto es que en ese proceso no se conoció de la cláusula suelo de 'su' contrato, ni de las circunstancias concurrentes en su celebración (arts. 4.1 de la Directiva 93/13/ CEE y 82.3 del texto refundido de la Ley General para la Defensa de los Consumidores y Usuarios), como, por ejemplo, el cumplimiento del principio de transparencia. El objeto controvertido, por tanto, entre ambos procesos es similar, pero no idéntico [...]” (STC 148/2016, FJ 6)».

En ambos casos analizados en estas SSTC se otorga el amparo y se declara la nulidad y retroacción de actuaciones para que el procedimiento individual continúe hasta el dictado de sentencia definitiva sobre el fondo. 
STC (Sala 1. ${ }^{a}$ ) núm. 5/2017, de 16 de enero (rec. 4591/2015), y STC (Sala 2. ${ }^{a}$ ) núm. 6/2017, de 16 de enero (rec. 1881/2016): vulneración del derecho a la tutela judicial sin indefensión a causa del emplazamiento edictal del ejecutado en proceso de ejecución hipotecaria pese a la constancia de domicilio extrarregistral

Estas SSTC 5/2017 y 6/2017 son las primeras del año 2017 que dictan sobre la consabida situación de indefensión en que se coloca al demandado - en este caso, ejecutado- cuyo domicilio consta en las actuaciones judiciales y, pese a ello, es emplazado por edictos. La peculiaridad de esta SSTC es que se refieren al proceso de ejecución hipotecaria y al deber de agotar los medios de notificación personal del ejecutado, aun en domicilios extrarregistrales, antes de acordar su notificación por edictos.

En el caso de la STC 5/2017, tras la adjudicación de varias fincas hipotecadas viene a conocimiento del demandante de amparo la existencia del proceso de ejecución hipotecaria en su contra, en cuyo seno insta el incidente de nulidad de actuaciones con expresa invocación de las SSTC 122/2013, de 20 de mayo; 131/2014, de 21 de julio, y 137/2014, de 8 de septiembre, relativas - todas ellas - a la jurisprudencia constitucional en torno al entonces vigente art. 686.3 LEC, relativo a la notificación personal del auto de despacho de la ejecución hipotecaria en el domicilio que conste en el Registro de la Propiedad y el deber de los órganos jurisdiccionales de agotar las posibilidades de averiguación del domicilio real antes de acudir a la comunicación edictal. La misma situación se produce en el caso examinado en la STC 6/2017, si bien en un estado procesal no tan avanzado.

En ambos casos se considera aplicable la doctrina constitucional de las SSTC 245/2006, de 24 de julio; 104/2008, de 15 de septiembre; 28/2010, de 27 de abril, y 150/2016, de 19 de septiembre: «Es necesario que el órgano judicial agote los medios que tenga a su alcance para notificar al ejecutado la existencia del proceso en su domicilio real, de modo que, una vez que surjan dudas razonables de que el domicilio señalado en la escritura del préstamo hipotecario y que figura en el Registro sea el domicilio real del ejecutado, le es exigible que intente, en cumplimiento del deber de diligencia que en orden a la realización de los actos de comunicación procesal le impone el art. 24.1 CE, el emplazamiento personal del ejecutado en el domicilio que figure en las actuaciones, distinto del que consta en la escritura de préstamo hipotecario y en el Registro». Y, especialmente, es de recordar, con la STC 122/2013, de 20 de mayo, que el art. 686.3 LEC, 
en la redacción dada por la Ley 13/2009, no dispensa al órgano judicial del «deber de intentar la notificación personal del demandado en el proceso de ejecución hipotecaria en caso de no ser posible practicarla en el domicilio que figure en la escritura de constitución de la hipoteca».

«Esta doctrina específica ha sido reiterada en las SSTC 131/2014, de 21 de julio, FJ 4; 137/2014, de 8 de septiembre, FJ 3; 89/2015, de 11 de mayo, FJ 3, y, más recientemente, en las SSTC 150/2016, FJ 2, y 151/2016, FJ 2, ambas de 19 de septiembre, todas relativas a procedimientos de ejecución hipotecaria, siendo destacable, como ya se advertía al inicio de este fundamento, la nueva redacción dada al precepto en cuestión por la Ley 19/2015, de 13 de julio (en su art. 1.25), que entró en vigor el 15 de octubre de 2015, incluyendo ahora expresamente la necesidad de que se efectúen las averiguaciones pertinentes para la localización del demandado en caso de no ser hallado en el domicilio que conste en el Registro de la Propiedad».

Así pues, en ambos casos examinados la Sala 1. ${ }^{a}$ y la Sala 2. ${ }^{a}$ coinciden en entender que ha existido una negativa manifiesta del deber de acatamiento de la doctrina jurisprudencial sobre el emplazamiento en forma personal en el proceso de ejecución hipotecaria y declaran vulnerados el derecho del recurrente a la tutela judicial efectiva sin indefensión (art. 24.1 $\mathrm{CE}$ ) con retroacción de actuaciones al momento inmediatamente siguiente a dictarse auto de despacho de la ejecución.

STC (Pleno) núm. 8/2017, de 19 de enero (rec. 2341/2012), y STC (Sala 2. ${ }^{a}$ ) núm. 10/2017, de 30 de enero (rec. 7088/2012): vulneración del derecho a la presunción de inocencia por denegación de indemnización por prisión provisional fundada en la inexistencia objetiva del hecho punible por dudas sobre los hechos típicos. Existencia de votos particulares

Estas dos SSTC representan todo un giro en la jurisprudencia - del TS- hasta ahora aplicable en materia de indemnización de la prisión provisional indebida (art. 294 LOPJ) y ambas cuentan con un voto particular. La senda seguida por el TC en ellas está en parte trazada por la jurisprudencia, de carácter más amplio, del TEDH en esta materia.

En el primero de los casos examinados, el de la STC (Pleno) núm. 8/2017, el demandante de amparo, que había estado en situación de prisión provisional durante algo más de un año, resultó absuelto por la AP de Almería por el carácter contradictorio de las diversas pruebas periciales sobre la sustancia que le fue incautada, hasta el punto de no saberse «qué sustancia se trata 
en realidad, y, por ende, si dicho producto causa grave daño a la salud». Tras la absolución, el demandante de amparo solicitó una indemnización por responsabilidad patrimonial del Estado ex art. 294 LOPJ, alegando la inexistencia objetiva del hecho punible, y esta solicitud ha sido desestimada con el conocido argumento de que la absolución del acusado en aplicación del principio in dubio pro reo no es exactamente equivalente a declarar probada la inexistencia objetiva del hecho punible, de manera que no es indemnizable la privación provisional de la libertad en aquellos procesos que finalizan con sentencia absolutoria basada en la presunción de inocencia.

El Pleno del TC, en esta importante STC 8/2017 que cuenta con un voto particular de su presidente, estima el amparo por vulneración del derecho a la presunción de inocencia y ordena la retrotracción de las actuaciones al momento anterior al dictado de la sentencia del TS, a fin de que este resuelva conforme a la más amplia interpretación que determina esta STC.

El TC señala, de entrada, que el resarcimiento de la prisión provisional en los supuestos de absolución no forma parte del contenido del derecho a la presunción de inocencia, sino que es un derecho de mera configuración legal. Ahora bien, cuestión distinta es que, establecida la responsabilidad del Estado por la prisión provisional indebida en los casos de absolución, el derecho a la presunción de inocencia no consiente que se distinga entre diferentes razones de absolución que, a la postre, permitan poner en cuestión la inocencia del acusado absuelto. Y así, el Pleno del TC considera que la desestimación de la indemnización basada en que la absolución «sólo» se fundó en el principio in dubio pro reo no es compatible con la doctrina del TEDH sobre el derecho a la presunción de inocencia, «pues emite sospechas sobre la culpabilidad del recurrente y utiliza la referencia a dicho derecho como elemento integrador de la relación de causalidad del daño producido en el ámbito de la responsabilidad patrimonial, lo que se estima inadecuado, pues para determinar si concurre o no la responsabilidad de la Administración de justicia por prisión provisional no podrán utilizarse argumentos que ni directa ni indirectamente afecten a la presunción de inocencia [...] Una vez que la absolución es firme - aunque se trate de una absolución con el beneficio de la duda- conforme al art. 6, $\mathbb{S}$ 2, del Convenio, la siembra de dudas sobre la culpabilidad, incluidas aquellas respecto de las causas de la absolución, no son compatibles con la presunción de inocencia (Rushiti, anteriormente citada, \$31) [...] El TEDH apunta que, en aplicación del principio in dubio pro reo, ninguna diferencia cualitativa debe existir entre una absolución fundada en una inexistencia de pruebas y una absolución resultante de una constatación de la inocencia de manera incontestable». 
Esta misma doctrina se reafirma en la posterior STC (Sala 2. $\left.{ }^{a}\right)$ núm. 10/2017, de 30 de enero, que examina el caso de un inculpado que estuvo casi cuatro años en situación de prisión provisional acusado de pertenencia a banda armada, siendo posteriormente absuelto por el TS. En los hechos declarados probados consta que el acusado, junto a otras personas, compartían ideas fanáticas de acabar con los infieles y eliminar líderes políticos, haciendo proselitismo interno de la yihad y de la sharia, pero sin participar en la imposición de estas ideas mediante violencia terrorista. La reclamación de la prisión provisional padecida es desestimada porque, aunque no existió prueba suficiente para probar la existencia del delito, el resultado probatorio no consiguió desvincular al acusado de los hechos que se le imputaban.

Pues bien, «el recurso de amparo ha de ser estimado por remisión a lo ya resuelto por el Pleno de este Tribunal en la STC 8/2017, de 19 de enero, resolución con la que el presente recurso guarda una identidad evidente. También en este supuesto las resoluciones impugnadas deniegan todas ellas la indemnización en consideración a que el principio in dubio pro reo, esto es, la insuficiencia de la prueba practicada para generar una convicción sobre la responsabilidad criminal más allá de toda duda razonable, ha sido el determinante de la absolución decretada en el proceso penal. Al operar así, las resoluciones administrativas y la resolución judicial que las confirma "cuestiona[n] la inocencia del demandante, lo que sucedía en los asuntos Puig Panella y Tendam [...] siguiendo la reciente STEDH de 16 de febrero de 2016 (asunto Vlieeland Boddy y Marcelo Lanni c. España) [...] de modo que se menospreció la presunción de inocencia»" (STC 8/2017, de 19 de enero, FJ 7). Con arreglo a esta doctrina, las decisiones recurridas en este proceso constitucional suscitan dudas sobre la inocencia del denunciante, razón por la que deben ser anuladas a efectos de que sean sustituidas por otras compatibles con el derecho del actor a la presunción de inocencia».

STC (Sala 2. ${ }^{a}$ ) núm. 12/2017, de 30 de enero (rec. 4090/2014): vulneración del derecho de acceso a la jurisdicción por la apreciación tardía y sin dar oportunidad previa de subsanar la falta de requisitos para entablar acciones por personas jurídicas que la demandante intentó subsanar temporáneamente

Esta STC permite al TC fijar doctrina sobre la interpretación del art. 45.2.d) LJCA y aclarar la existente sobre la subsanación de la omisión 
de requisitos procesales, especialmente en lo que se refiere al ámbito contencioso-administrativo, en relación con los arts. 45.3 y 138 LJCA.

La sentencia impugnada inadmitió un recurso contencioso-administrativo interpuesto ante la Sala de lo Contencioso-Administrativo del TSJ de Madrid debido al incumplimiento del requisito relativo al ejercicio de acciones por una persona jurídica [art. 45.2.d) LJCA] que, antes de su apreciación de oficio, se había intentado subsanar a través de una escritura de poder que el TSJ consideró materialmente insuficiente en la sentencia definitiva. El defecto había sido denunciado por la Abogacía del Estado en su escrito de contestación a la demanda, pero, tras la aportación de la escritura ex art. 138.1 LJCA y las posteriores alegaciones de la demandante en trámite de conclusiones, renunció a su alegación en igual momento procesal. Así pues, el tribunal a quo la apreció de oficio en sentencia sin haber dado previamente una oportunidad ad hoc para subsanar la omisión, con el resultado de haber dejado imprejuzgado el fondo del recurso.

Lo que diferencia este supuesto del examinado en la STC 14/2008, de 31 de enero, es que la ahora demandante, frente a la alegada concurrencia de un defecto procesal, no se mantuvo inactiva, sino que «reaccionó de manera diligente en la debida forma y sin necesidad de requerimiento judicial alguno». No pudo representarse, pues, la insuficiencia del poder otorgado por el secretario y los insertos acuerdos congresuales de la persona jurídica demandante. Esta inadmisión «sin dar opción a la subsanación de la deficiencia advertida en la misma, ha incurrido en un rigor excesivo en la apreciación del cumplimiento del requisito del art. 45.2.d) LJCA, que ha supuesto la vulneración de su derecho a la tutela judicial efectiva.

En primer lugar, el órgano judicial no ha tomado en consideración en ningún momento la diligencia con la que actuó la actora en cuanto tuvo conocimiento de la causa de inadmisión opuesta por la Abogacía del Estado [...] sin embargo, aquí la decisión judicial equipara la pasividad absoluta con la actuación diligente [...] El problema es que, siguiendo la tesis mantenida en la Sentencia aquí impugnada, al litigante que, diligentemente, se ha acogido a la previsión del art. 138.1 LJCA, se le coloca en una situación de incertidumbre, dado que no va a tomar conocimiento del parecer del órgano judicial sobre la cuestión hasta que se dicte sentencia, que podrá ser incluso de inadmisión si este entiende que existe el defecto y que no queda corregido con lo alegado o aportado, momento en el que la parte recurrente ya no contará con la posibilidad de subsanarlo. Y esta consecuencia no resulta satisfactoria desde la perspectiva del derecho fundamental a la tutela judicial efectiva consagrado en el art. 24.1 CE». Por 
tanto, la Sala a quo, «de acuerdo con las exigencias del art. 24.1 CE, estaba obligada a actuar en los términos de la previsión del art. 138.2 LJCA, suspendiendo el plazo para dictar sentencia y concediendo otro de diez días a la parte actora para la subsanación del defecto. Al no haber procedido así, dictando, en cambio, directamente una sentencia de inadmisión del recurso, el órgano judicial lesionó el derecho de la recurrente a la tutela judicial efectiva en su vertiente de acceso a la jurisdicción».

\section{STC (Sala 2. ${ }^{a}$ ) núm. 13/2017, de 30 de enero (rec. 7301/2014): vulneración de los derechos a la libertad personal y a la asistencia letrada del detenido por la negativa a proporcionar copia del atestado policial al letrado}

Detenidas dos personas a las que se atribuye la comisión de varios delitos de robo y pertenencia a grupo criminal, el abogado designado de oficio para su asistencia letrada impugna la detención por insuficiente información sobre los motivos que la justifican, por exceso en el plazo de su duración y por denegarse al letrado el acceso a los materiales del expediente para poder realizar su labor de defensa, con el resultado de haber resultado imposible asesorar al detenido sobre la conducta a observar durante la toma de declaración, incluyendo la de guardar silencio.

La solicitud de habeas corpus fue denegada por el Juzgado de Primera Instancia e Instrucción núm. 4 de Illescas mediante Auto de 13 de julio de 2014, que declaró conforme a derecho la privación de libertad de los detenidos y las circunstancias en las que se estaba realizando; en particular, sobre la alegada vulneración del derecho a la asistencia letrada por no poder acceder a las actuaciones, el Juzgado consideró que, si bien este derecho es aplicable en nuestro ordenamiento por el efecto útil del art. 7 de la Directiva 2012/13, de 22 de mayo, no se daba el supuesto de hecho de la norma, «toda vez que en el momento en que se ha solicitado el habeas corpus no existe, como tal, dicho expediente, pues los agentes se encuentran practicando diligencias y confeccionando el atestado».

Interpuesta demanda de amparo, la Sala 2. ${ }^{a}$ del TC se centra en el examen del derecho a la asistencia jurídica al detenido del art. 17.3 CE, frente al derecho - también específico- de asistencia letrada al imputado o acusado referido en el art. 24.2 CE.

Con cita de la STC 199/2003, de 10 de noviembre, recuerda que «el derecho del detenido a la asistencia letrada en las diligencias policiales y judiciales, reconocido en el art. 17.3 CE, adquiere relevancia constitucio- 
nal como una de las garantías del derecho a la libertad protegido en el apartado primero del propio artículo. En este sentido su función consiste en asegurar que los derechos constitucionales de quien está en situación de detención sean respetados, que no sufra coacción o trato incompatible con su dignidad y libertad de declaración, y que tendrá el debido asesoramiento técnico sobre la conducta a observar en los interrogatorios, incluida la de guardar silencio, así como sobre su derecho a comprobar, una vez realizados y concluidos con la presencia activa del letrado, la fidelidad de lo transcrito en el acta de declaración que se le presenta a la firma (por todas, SSTC 196/1987, de 11 de diciembre, FJ 5; 252/1994, de 19 de septiembre, FJ 4, y 229/1999, de 13 de diciembre, FJ 2)».

Si bien al tiempo de la detención de los demandantes ningún precepto de la LECrim reconocía el derecho de acceso del abogado a las actuaciones policiales, este derecho resultaba existente por la aplicación directa del art. 7.1 de la — por entonces, no traspuesta- Directiva 2012/13/UE, de 22 de mayo de 2012. Y en este contexto, «la negativa sin justificación alguna del instructor a la entrega del material del que ya disponía trajo consigo así la vulneración del derecho a la asistencia de letrado (art. 17.3 CE), el cual incluye en su contenido el derecho del detenido y su letrado a acceder a los elementos fundamentales (entonces, art. 7.1 de la Directiva 2012/13/ UE) para impugnar su situación privativa de libertad [...].

La vulneración del derecho a la asistencia de letrado (art. 17.3 CE), en los términos que acaban de explicarse, trae consigo también la del derecho a la libertad individual (del art. 17.1 CE) de los recurrentes, puesto que su detención gubernativa no tuvo lugar con observancia de lo previsto en el ordenamiento. Procede, por tanto, el otorgamiento del amparo que se solicita, con nulidad del Auto desestimatorio de la solicitud de habeas corpus impugnado [...] sin perjuicio de lo que pueda haberse acordado con posterioridad por el Juzgado de Instrucción núm. 3 de Aranjuez, en las diligencias previas que se abrieron con posterioridad contra ambos».

STC (Sala 2. ${ }^{a}$ ) núm. 14/2017, de 30 de enero (rec. 1920/2015), y STC (Sala 1. ${ }^{\text {) }}$ núm. 29/2017, de 27 de febrero (rec. 3279/2014): necesidad de ponderar las circunstancias personales y familiares del extranjero condenado por delito doloso antes de acordar su expulsión de territorio nacional

Estas dos SSTC siguen la línea de la STC 131/2016, de 18 de julio, y de la STC 201/2016, de 28 de noviembre, relativas al deber de motivación 
reforzada de las resoluciones de expulsión de territorio nacional, con prohibición de entrada por cinco años, de extranjeros condenados por delito doloso dictadas al amparo del art. 57.2 LOEx, cuando se alegan circunstancias de arraigo social, laboral y familiar por el interesado.

En el caso de la primera STC, la Sala 2. ${ }^{a}$ del TC aprecia que «la argumentación proporcionada por las resoluciones judiciales impugnadas, que excluye la ponderación de las circunstancias personales y familiares del recurrente por no contemplar el art. 57.2 LOEx una sanción, no puede ser aceptada pues "[a]l estar en juego, asociados a derechos fundamentales como los contemplados en los arts. 18.1 y 24.2 CE (STC 46/2014, FJ 7), una pluralidad de intereses constitucionales como el de protección social, económica y jurídica de la familia (art. 39.1 CE)", es preciso en todo caso "ponderar las circunstancias de cada supuesto» y «tener en cuenta la gravedad de los hechos" (STC 46/2014, de 7 de abril, FJ 7, y 131/2016, de 18 de junio, FJ 6) [...].

Al haberse consumado la vulneración del derecho fundamental en las dos resoluciones judiciales impugnadas, debe acordarse la nulidad de éstas y la retroacción de las actuaciones al momento inmediatamente anterior al de dictarse la Sentencia».

Esta doctrina se reitera en la posterior STC (Sala 1. ${ }^{a}$ ) núm. 29/2017, de 27 de febrero (rec. 3279/2014), en la que también se ha considerado vulnerado el derecho a obtener una resolución motivada y fundada en Derecho por la decisión del tribunal penal de sustituir, sin más, la pena de prisión de dos años impuesta a la extranjera por la de expulsión del territorio nacional y la prohibición de entrada en España por un plazo de seis años, pese a la alegación de circunstancias concretas de arraigo personal y familiar.

STC (Pleno) núm. 15/2017, de 2 de febrero (rec. inconst. 1024/2013); STC (Pleno) núm. 35/2017, de 1 de marzo (rec. inconst. 3076/2013), y STC (Pleno) núm. 35/2017, de 1 de marzo (rec. inconst. 5046/2016): pérdida sobrevenida de objeto de recurso de inconstitucionalidad contra diversos preceptos relativos a las tasas judiciales de la Ley 10/2012, de 20 de noviembre

Siguiendo la senda iniciada por la STC 140/2016, de 21 de julio, por la que se desestimó el recurso de inconstitucionalidad planteado por más de cincuenta diputados del Grupo Parlamentario Socialista en el Congre- 
so de los Diputados contra varios artículos de la Ley 10/2012, también en la STC (Pleno) núm. 15/2017 se acuerda la terminación del recurso a causa de la pérdida sobrevenida de objeto.

Tras la reforma de la citada Ley por medio del posterior Real Decreto-ley $1 / 2015$, de 27 de febrero, y de la Ley 25/2015, de 28 de julio, relativas a la exención del pago de la tasa a las personas físicas, las reglas relativas al pago de la tasa han dejado de ser aplicables a las personas físicas de forma no meramente coyuntural. También concurre la pérdida sobrevenida de objeto en relación con aquellos preceptos de la Ley 10/2012 impugnados en el presente recurso y que ya han sido declarados inconstitucionales y nulos por la citada STC 140/2016.

Sobre la misma materia se han dictado posteriormente otras dos sentencias de Pleno más en el mismo sentido.

En primer lugar, la STC (Pleno) núm. 24/2017, de 16 de febrero (rec. inconst. 3035/2013), va referida a la inconstitucionalidad de los apartados 1 a 8 del art. 1 del Real Decreto-ley 3/2013, de 22 de febrero, por el que se modifica el régimen de las tasas en el ámbito de la Administración de Justicia y el sistema de asistencia jurídica gratuita. También en esta sentencia se pone fin al proceso por pérdida sobrevenida del objeto del recurso.

$\mathrm{Y}$ en segundo lugar y sobre la misma norma, la STC (Pleno) núm. 35/2017, de 1 de marzo (rec. inconst. 3076/2013), ha declarado también la terminación del recurso por pérdida sobrevenida de objeto.

STC (Sala 2. ${ }^{a}$ ) núm. 22/2017, de 13 de febrero (rec. 5046/2015): vulneración del derecho a la tutela judicial efectiva por no aplicar la jurisprudencia del TC sobre la inidoneidad de la querella para interrumpir por sí sola la prescripción penal

La demanda de amparo se dirige contra la sentencia de apelación de la AP de Almería (y el auto que desestimó el incidente de nulidad de actuaciones formulado frente a ella), así como contra la sentencia del Juzgado de lo Penal núm. 5 de Almería, que condenaron al demandante de amparo como autor de un delito de apropiación indebida, pese a hallarse prescrita la responsabilidad penal conforme a la jurisprudencia del TC.

En esta STC la Sala 2. ${ }^{a}$ del TC aprecia que la AP Almería «se apartó conscientemente de la doctrina del Tribunal Constitucional sobre la prescripción de las infracciones penales» contenida en las SSTC 63/2005, de 
14 de marzo, y 29/2008, de 20 de febrero, esto es, sobre la inidoneidad de la querella como acto interruptor del cómputo del plazo de prescripción de la acción penal a los efectos del art. 132.2 CP en su redacción anterior a la Ley Orgánica 5/2010. En concreto, considera contrario a la jurisprudencia constitucional que, establecido el dies a quo de la prescripción en la entrega del dinero distraído (el día 31 de octubre de 2007) y no en el momento en que se requiere la devolución (el día 31 de marzo de 2009), como hizo la Sentencia de instancia, el plazo de prescripción se considere interrumpido por la interposición de la querella (el día 15 de mayo de 2009) sin exigir un posterior acto de interposición judicial dentro del plazo de prescripción. La AP descartó la aplicación del art. 132.2 CP vigente en el momento de enjuiciar los hechos (redacción dada por la Ley Orgánica 5/2010, donde no basta la mera presentación de la querella o denuncia), por no estar vigente en el momento de presentación de la querella. Y también rechazó aplicar la doctrina de la STC 63/2005, de 14 de marzo, basándose, sin más, en la decisión del Pleno no jurisdiccional de la Sala Segunda del Tribunal Supremo de 25 de abril de 2006.

«Tal negativa al acatamiento de nuestra doctrina supone una quiebra del mandato recogido en el citado art. 5.1 LOPJ, de la que deriva la consiguiente lesión del derecho del demandante a la tutela judicial efectiva consagrada en el art. 24.1 CE, en coherencia con la doctrina de este Tribunal (por todas, las SSTC 29/2008, de 20 de febrero, FJ 10; 147/2009, de 15 de junio, FJ 2; 195/2009, de 28 de septiembre, FJ 6; 206/2009, de 23 de noviembre, FJ 3; 37/2010 de 19 de julio, FJ 2; 133/2011, de 18 de julio, FJ 3; 2/2013, de 14 de enero, FJ 7, y 51/2016, de 14 de marzo, FJ 1)».

Este razonamiento no es extrapolable a la sentencia del Juzgado de lo Penal, por la razón de que, para el cómputo de la prescripción, el Juzgado tomó como dies a quo una fecha posterior a la empleada por la AP. Ahora bien, puesto que queda extramuros de la función del TC delimitar con mayor precisión si efectivamente el hecho prescribió o no y conforme a qué criterio en el supuesto examinado, corresponde anular la sentencia y el auto de la AP a fin de que por esta se pronuncie otra respetuosa con el derecho a la tutela judicial efectiva vulnerado. 
STC (Sala 2. ${ }^{a}$ ) núm. 30/2017, de 27 de febrero (rec. 22/2015): vulneración del derecho a la tutela judicial efectiva en relación con el derecho a una resolución motivada sobre la revisión de sentencias contenciosoadminitrativas firmes basada en la insconstitucionalidad sobrevenida de la ley aplicada

Impuesta una sanción al demandante de amparo, titular de una licencia de taxi, por haber recogido a un viajero fuera de las paradas establecidas en un aeropuerto, fue recurrida en vía contencioso-administrativa, donde fue confirmada. La sanción tenía su fundamento jurídico en un precepto legal de la Ley 20/1998, de 27 de noviembre, de Ordenación y Coordinación de los Transportes Urbanos de la Comunidad de Madrid, que fue declarado inconstitucional y nulo por falta de concreción legal de los elementos esenciales de la infracción, en virtud de la STC 13/2013, de 28 de enero.

El demandante de amparo suscita entonces incidente de ejecución de sentencia para que se procediera bien a la inejecución de la sentencia, bien a declarar la nulidad de actuaciones conforme al art. 53.2 CE, en relación con los arts. 238.6, 240 y 241 LOPJ, por aplicación del art. 40.1 LOTC; esto es, por la posibilidad de revisar sentencias contencioso-administrativas firmes en las que se hayan aplicado disposiciones declaradas inconstitucionales, «siempre que, como consecuencia de la nulidad de la norma aplicada, resulte una reducción de la sanción o una exclusión, exención o limitación de la responsabilidad».

El Juzgado deniega, mediante auto, la solicitud por ser tasados los motivos de nulidad de los actos procesales, no estar prevista esta circunstancia como motivo de revisión de sentencia y ser, en todo caso, la sentencia de carácter declarativa, por limitarse a confirmar la sanción administrativa.

Presentada demanda de amparo, la Sala 2. ${ }^{a}$ del TC la estima y declara vulnerado el derecho fundamental del demandante a la tutela judicial efectiva sin indefensión del art. 24.1 CE en relación al art. 25.1 CE, por ser exigible una motivación reforzada en la respuesta judicial de aquellas cuestiones que comprometen el derecho a la legalidad penal y sancionadora del art. 25.1 CE. Las causas de la vulneración son varias.

En primer lugar, la decisión del Juzgado niega irrazonablemente que se dieran los presupuestos tasados para la promoción del incidente de nulidad de actuaciones, pese a que en él puede alegarse la vulneración de cualquier derecho fundamental, como el principio de legalidad del art. 25.1 CE que se infiere de la alegación de la STC 13/2013. 
En segundo lugar, la decisión del Juzgado también omite todo razonamiento que sustente la afirmación de que no es posible reconducir la alegación del demandante a los motivos de revisión del art. 102 LJCA, a pesar de la terminante previsión del art. 40.1 in fine LOTC.

$\mathrm{Y}$, en tercer lugar, donde el razonamiento del Juzgado «quiebra de manera patente y no satisface ni la motivación reforzada ni el canon mínimo exigible a una resolución fundada en Derecho es en la interpretación que efectúa del art. 40.1 in fine LOTC, cuando afirma que este precepto sólo permite la revisión de sentencias firmes en materia sancionadora en las que se haya aplicado una ley posteriormente declarada inconstitucional "si no se ha ejecutado la sanción" [...] El órgano judicial ha adoptado una decisión carente de sustento legal o doctrinal, por lo que resulta irrazonable, de acuerdo con la definición que de estos conceptos ha dado este Tribunal [...] Y esto es, precisamente, lo que ocurre en el presente caso, en el que el razonamiento del órgano judicial parte de una premisa no contemplada en el art. 40.1 LOTC en relación a la revisión de procesos penales o de carácter sancionatorio, como es la supuesta exigencia de que las sanciones impuestas no hayan sido totalmente ejecutadas».

STC (Sala 1. ${ }^{a}$ ) núm. 39/2017, de 24 de abril (rec. 332/2016): vulneración del derecho a la tutela judicial efectiva en relación con el derecho a la integridad física y moral, por no haberse agotado todas las vías de investigación en una causa de malos tratos a un detenido en situación de incomunicación

En el marco de una operación antiterrorista dirigida por el Juzgado Central de Instrucción núm. 3, el demandante de amparo fue arrestado en régimen de detención incomunicada por agentes de la Guardia Civil y trasladado a diversos lugares de San Sebastián y Pamplona para practicar registros en su presencia. Trasladado a Madrid, fue objeto de diversos interrogatorios policiales, relató al médico forense los malos tratos sufridos y solicitó el babeas corpus, que fue inadmitido a trámite por el Juzgado Central de Instrucción núm. 3. En su declaración ante este Juzgado tres días más tarde volvió a referir las torturas padecidas mientras se hallaba bajo custodia policial.

Por estos hechos el demandante de amparo presentó denuncia ante los Juzgados de Instrucción de Pamplona en el que interesaba la práctica de diversas diligencias de investigación. El Juzgado de Instrucción accedió a incorporar los informes médico-forenses efectuados durante su detención 
y, a la vista de su contenido, dictó auto de sobreseimiento provisional por no aparecer debidamente justificada la perpetración de los hechos. Recurrido el sobreseimiento en apelación, la AP estimó en parte el recurso y ordenó practicar las diligencias que estimó pertinentes y útiles, tras las cuales el Juzgado dictó nuevo auto de sobreseimiento que ha sido sucesivamente confirmado y ha devenido firme. La demanda de amparo denuncia la vulneración del derecho a la integridad física y moral (art. $15 \mathrm{CE}$ ), por no haberse desarrollado un procedimiento judicial exhaustivo sobre los hechos denunciados, y la vulneración del derecho a la tutela judicial efectiva (art. 24.1 CE), en relación con los derechos a un proceso con todas las garantías y a utilizar los medios de prueba pertinentes para la defensa (art. 24.2 CE) conforme a la interpretación de la jurisprudencia constitucional y del Tribunal Europeo de Derechos Humanos. El Ministerio Fiscal ha interesado la estimación de la demanda de amparo.

La Sala 1. ${ }^{\text {a }}$ del TC recuerda la jurisprudencia establecida en la extensa STC 130/2016, de 18 de julio, y la consolidada jurisprudencia del TEDH que han establecido la necesidad de un canon reforzado de investigación cuando se trata de denuncias de torturas y malos tratos por parte de agentes de los cuerpos de seguridad del Estado, más riguroso — si cabe- en los supuestos en los que el denunciante se ha encontrado en situación de detención incomunicada (SSTEDH de 28 de septiembre de 2010, asunto San Argimiro Isasa c. España, $\mathbb{S} 34$; de 16 de octubre de 2012, asunto Otamendi Egiguren c. España, $\mathbb{\$} 38$; de 7 de octubre de 2014, asunto Ataun Rojo c. España; de 7 de octubre de 2014, asunto Etxebarria Caballero c. España; de 5 de mayo de 2015, asunto Arratibel Garciandia c. España, y de 31 de mayo de 2016, asunto Beortegui Martínez c España).

La aplicación al caso de esta doctrina jurisprudencial conduce a apreciar que «la decisión de archivar las diligencias penales abiertas como consecuencia de la denuncia por torturas del recurrente no puede considerarse conforme con las exigencias derivadas del deber de investigación judicial eficaz y suficiente de este tipo de denuncias [...] La falta de corroboración en los informes médico-forenses (así como en el informe pericial psicológico) de los malos tratos que el recurrente afirma haber sufrido durante su detención incomunicada, esgrimida en los Autos impugnados como argumento central para descartar la verosimilitud de la denuncia, no invalida la sospecha de la existencia de ese maltrato policial [...] unos malos tratos como los denunciados no dejarían necesariamente marcas o señales de su comisión, por lo que la ausencia de signos de agresiones físicas no es concluyente (SSTC 107/2008, de 22 de septiembre, FJ 3; 
40/2010, de 19 de julio, FJ 3; 131/2012, de 18 de junio, FJ 4, y 144/2016, de 19 de septiembre, FJ 3, por todas) [...] Puede existir otro tipo de datos que - desde la perspectiva del deber de profundizar en la investigacióngenere un panorama sospechoso potencialmente conectado con la existencia de torturas o malos tratos, incluso aunque los mismos fueran claramente insuficientes para sustentar una condena penal por delito de torturas o malos tratos (SSTC 123/2008, de 20 de octubre, FJ 3; 12/2013, de 28 de enero, FJ 3; 153/2013, de 9 de septiembre, FJ 4, y 144/2016, FJ 3).

Conforme a lo expuesto debe concluirse que no se apuró al máximo la instrucción y, por ende, que resulta precipitada la afirmación de que no existen indicios de la perpetración de los hechos denunciados, pues las razones ofrecidas por los órganos judiciales en los Autos impugnados para llegar a tal conclusión no resultan acordes con el deber de motivación reforzada, constitucionalmente exigible en estos casos».

STC (Sala 1. ${ }^{a}$ ) núm. 41/2017, de 24 de abril (rec. inconst. 5077/2016): inconstitucionalidad, por vulneración del derecho a una resolución sobre el fondo, del precepto foral navarro que impide a los progenitores la reclamación de la filiación no matrimonial

El JVM núm. 1 de Tafalla eleva cuestión de inconstitucionalidad contra la Ley 71 de la compilación de Derecho civil foral de Navarra, cuyo largo y expositivo apartado $b$ ) no prevé la posibilidad de que el progenitor pueda reclamar una filiación no matrimonial en los casos de falta de posesión de estado, razón por la que la norma foral podría no ser compatible con los arts. 39.2 y 24.1 CE (en su vertiente de derecho de acceso a la jurisdicción). En concreto, la norma permite a los hijos no matrimoniales - pero no a los progenitores - reclamar la declaración de paternidad o maternidad no matrimonial en cinco supuestos, a saber: «1. Cuando la madre y el padre presuntos hubiesen convivido notoriamente durante el tiempo de la concepción. 2. Cuando haya posesión de estado de hijo respecto del demandado. 3. Cuando exista declaración del presunto progenitor. 4. Cuando haya pruebas biológicas de la relación paterno-filial. 5. Cuando respecto a la maternidad haya pruebas del parto».

Para el TC, «el citado apartado b) de la ley 71 de la Compilación de Derecho civil foral de Navarra es contrario a los arts. 24.1 y 39.2 CE, por excluir a los progenitores del ejercicio de la acción conducente a la declaración de paternidad o maternidad en los casos de filiación no matrimonial. 
Las razones para sustentar esta declaración de inconstitucionalidad son plenamente coincidentes con las expuestas por el Pleno de este Tribunal en la STC 273/2005, de 27 de octubre, FFJJ 5 a 7 , y reiteradas en la STC 52/2006, de 16 de febrero, FJ 2, en que se declaró la inconstitucionalidad del art. 133 del Código civil (CC), en la redacción dada por la Ley 11/1981, de 13 de mayo, conforme al cual la acción de reclamación de la filiación, cuando faltara la respectiva posesión de estado, correspondía únicamente al hijo durante toda su vida [...].

En el caso que nos ocupa, la regulación del apartado b) de la ley 71 de la Compilación de Derecho civil foral de Navarra es aún más rígida que la que se contenía en el art. 133 CC, pues éste sólo restringía la legitimación para reclamar la filiación no matrimonial al hijo cuando no existiera posesión de estado, mientras que en el supuesto de la norma foral, sólo se reconoce legitimación para reclamar la declaración de la filiación no matrimonial al hijo (y, en determinados supuestos, a sus descendientes) en los casos específicamente contemplados por la propia norma, incluido el supuesto de existencia de posesión de estado (párrafo 2). Es decir, que a diferencia de lo que sucedía en el Código Civil, ni siquiera en el caso de existir posesión de estado podrán los progenitores reclamar la declaración de la filiación no matrimonial, otorgándose una absoluta prevalencia al hijo en detrimento de aquéllos, sin que, como ya se dijo en la STC 273/2005, FJ 7, el sacrificio que se les impone resulte constitucionalmente justificado, puesto que, aparte de que podría haber sido sustituido por la imposición de determinadas limitaciones, el sistema articulado por la propia Compilación impide el planteamiento y la obligada sustanciación de acciones que resulten absolutamente infundadas, desde el momento en que, al establecer las disposiciones generales en la materia, la ley 70 de la Compilación prevé expresamente, en términos similares al art. 767.1 de la Ley de Enjuiciamiento Civil (LEC), que el juez "no admitirá la demanda si con ella no se presenta un principio de prueba de los hechos en que se funde"».

En cuanto a los efectos de la inconstitucionalidad — que en este caso deriva de quedar excluidos los progenitores del círculo de sujetos legitimados-, no procede declarar la nulidad de la norma por los efectos perniciosos que produciría la desaparición de una acción que beneficia a los sujetos que sí están incluidos en ella: «Por tanto, al tratarse de una omisión del legislador contraria a la Constitución que no puede ser subsanada mediante la anulación del precepto, la apreciación de la inconstitucionalidad por insuficiencia normativa del mismo exige que sea el legislador [...] el que regule con carácter general la legitimación de los progenitores para recla- 
mar la filiación no matrimonial, con inclusión, en su caso, de los requisitos que se estimen pertinentes para impedir la utilización abusiva [...] En todo caso, corresponde al legislador, en el plazo de un año, dar respuesta normativa a la situación planteada».

STC (Sala 2. ${ }^{a}$ ) núm. 40/2017, de 24 de abril (rec. 351/2016): extensión de los efectos retroactivos de la nulidad, por inconstitucionalidad, de la Ley 10/2012, de Tasas Judiciales, a procesos en los que el pago haya obstaculizado el acceso al recurso

Con ocasión de la notificación de la sentencia dictada en un proceso seguido en rebeldía contra la ahora demandante de amparo, esta promueve, sucesivamente, incidente excepcional de nulidad de actuaciones y recurso de apelación, a fin de denunciar los defectos de emplazamiento generadores de indefensión. En fase de admisión del recurso se requiere a la apelante la acreditación del pago de la tasa judicial correspondiente (800 euros), frente al que se alega - entre otros motivos - la falta de recursos suficientes para poder afrontarlo y, en la cadena de recursos que siguieron, la jurisprudencia constitucional y los cambios normativos sobrevenidos en esta materia.

Llegado al TC, se admite a trámite la demanda de amparo por la inexistencia de doctrina sobre el particular que se plantea y que no es otro que precisar la aplicación de la STC 140/2016 y de la limitación de efectos de la STC 227/2016 a otros procesos pendientes como el presente, en el que se ha aplicado ultraactivamente la normativa nula. «El acto de aplicación de dicha normativa - a la que atendieron los órganos judiciales por estar entonces vigente- actualiza la misma vulneración que apreciamos en la norma de referencia en la que tienen su fuente, por vulnerarse el derecho de acceso a los recursos (art. 24.1 CE)».

\section{TRIBUNAL SUPREMO: SALA 1. ${ }^{a}$ O DE LO CIVIL}

STS (Sala 1. ${ }^{a}$ ) núm. 1/2017, de 10 de enero (rec. 944/20014): incompetencia de los tribunales españoles a causa de forum shopping artificialmente provocado mediante una acumulación subjetiva de acciones para sustraer al principal demandado de su foro de defensa

Esta STS confirma la de la AP de Alicante en apelación y estima que la conducta de la demandante (la sociedad BMW), al demandar a Aca- 
cia SRL ante un tribunal español, había incurrido en una conducta de búsqueda deliberada de un tribunal cuya jurisprudencia le fuera favorable; esto es, en una práctica de forum shopping, contraria al principio de previsibilidad que inspira la normativa comunitaria, por pretender que la competencia del tribunal del domicilio de un simple taller que vende «llantas de sustitución» atrajera la competencia internacional para conocer de la acción de mayor importancia, que no es otra que la ejercitada contra la empresa fabricante y distribuidora de las llantas, domiciliada en Italia.

En concreto, la Sala 1. ${ }^{a}$ confirma la falta parcial de competencia internacional de los juzgados mercantiles de Alicante (en cuanto tribunales nacionales de marca comunitaria) para conocer de una demanda interpuesta por la empresa alemana BMV por infracción de diseños industriales comunitarios (en el caso, varios modelos de llantas para los vehículos de su marca) dirigida simultáneamente contra: 1) una empresa italiana fabricante de llantas de sustitución (que, significativamente, es uno de los mayores proveedores europeos de este tipo de mercado), respecto de la que se declara la falta de competencia internacional, y 2) un taller de automóviles español que, aunque no mantiene relaciones societarias ni comerciales directas con la empresa italiana, tiene a la venta sus productos, motivo por el que se allanó a la demanda.

La demandante ha basado la competencia judicial internacional en el foro de conexión del art. 6.1 del Reglamento (CE) núm. 44/2001 a causa de tener el vendedor demandado su domicilio en España y estar vinculado este y el fabricante codemandado por una relación tan estrecha que resultaba oportuno tramitar y juzgar las acciones ejercitadas contra ambos al mismo tiempo a fin de evitar resoluciones que podrían ser inconciliables si los asuntos fueren juzgados separadamente.

La empresa italiana demandada interpuso declinatoria, que fue desestimada en primera instancia, por la que se alegó la falta de competencia internacional por considerar que la conducta de BMW era constitutiva de forum shopping, en cuanto la demandante pretendía eludir el tribunal del domicilio del demandado en Nápoles, donde ya se había fallado la misma cuestión en sentido desfavorable para BMW y favorable para la empresa italiana, para acogerse a la jurisdicción española, donde se había fallado la cuestión en sentido inverso; el fondo del asunto versa sobre el ámbito de la llamada cláusula de reparación o must-much del art. 110 del Reglamento núm. 6/2002 del Consejo, de 12 de diciembre de 2001, sobre los dibujos y modelos comunitarios, en virtud de la cual cabe fabricar recambios o accesorios de productos complejos integrados por múltiples componen- 
tes que indiquen el destino de un producto o de un servicio, con objeto de permitir la reparación de dicho producto complejo para devolverle su apariencia inicial, pese a que el producto complejo esté registrado como propiedad industrial.

La Audiencia Provincial revocó la decisión del Juzgado Mercantil y apreció la falta de competencia judicial internacional y, con ella, la nulidad de todo lo actuado frente a la empresa demandada italiana; resolución frente a la que BMW interpone - en lo que nos interesa- el recurso extraordinario por infracción procesal que es desestimado por el TS en un extenso fundamento de Derecho tercero dedicado a «la competencia judicial internacional por conexidad en los litigios sobre dibujos y modelos comunitarios», cuya ultima ratio se ubica en la previsibilidad de los tribunales competentes.

El TS analiza, en primer lugar, los foros específicos del Reglamento (CE) núm. 207/2009 del Consejo, de 26 de febrero de 2009, sobre la marca de la Unión Europea, y del Reglamento (CE) núm. 6/2002 del Consejo, de 12 de diciembre de 2001, sobre los dibujos y modelos comunitarios. Este último establece, para el conocimiento de las acciones de infracción, el foro general del domicilio del demandado (art. 82.1) y, junto a él, introduce el foro alternativo del lugar de comisión de la infracción (art. 82.5), con la importante limitación de que entonces el tribunal «será competente tan sólo sobre las violaciones cometidas o que puedan cometerse en el territorio del Estado miembro en el que se encuentre dicho Tribunal» (art. 83.2, que introduce el llamado principio de mosaico).

El TS se detiene en este segundo foro —el del lugar de comisión de la infracción- al que acaba aplicando la interpretación restrictiva validada en la STJUE de 5 de junio de 2014, asunto C-360/12, consistente en entender que el foro debe estar relacionado «con un comportamiento activo del autor de dicha violación»; esto es, que la conexión en la que se basa este foro es la de que al demandado infractor «le es imputable una conducta activa en el territorio del Estado en cuestión», no bastando con que la violación produzca efectos en el territorio del Estado miembro. En lo demás, el reglamento específico hace una remisión a la normativa general que regula la competencia judicial internacional en el espacio UE, que - tiempo del proceso- hay que entender hecha al Reglamento núm. 44/2001 y, en concreto, a su art. 6.1, que debe ser interpretado de forma estricta por constituir una excepción al foro general del domicilio del demandado.

Por tanto, centrado el problema jurídico en la aplicación del art. 6 del Reglamento núm. 44/2001 que invoca el demandante como infringido, el 
TS trae a colación la jurisprudencia del TJUE sobre el foro de la conexión de acciones y sobre sus límites, fundados en «la exigencia de previsibilidad en la determinación del tribunal competente internacionalmente y la interdicción del abuso de derecho y el fraude de ley [...] como la consistente en crear o mantener de forma artificial las condiciones de aplicación de esa disposición en el momento de ejercitarse la acción» (repudiada en la STJUE de 21 de mayo de 2015, asunto C-352/13).

A la vista de la jurisprudencia del TJUE, el TS estima sustancialmente correcta la aplicación al caso que ha hecho la AP de Alicante de los foros de competencia judicial internacional del Reglamento núm. 6/2002, en atención a la falta de vínculos contractuales o societarios entre las empresas demandadas y a la existencia de resoluciones previas españolas que fueron favorables a los intereses de la empresa demandante. Para la AP de Alicante, la demandante «ha buscado de propósito sustraer a Acacia del tribunal de su domicilio, el de Nápoles, acumulando la acción ejercitada contra dicha sociedad italiana, uno de los principales proveedores de llantas de sustitución en la Unión Europea, a la acción ejercitada contra un simple taller de reparación radicado en España, con lo que pretendía atraer a Acacia a la competencia del tribunal del domicilio de dicho taller para sustraerse al criterio jurisprudencial del tribunal del domicilio del principal demandado, que le era desfavorable». Dice el TS que aunque algunos argumentos (en especial los relativos a la diversa situación de Derecho) pueden no ser compartidos, los argumentos principales de la fundamentación jurídica de la sentencia sí lo son.

«Ciertamente, la posibilidad de elección del fuero por parte del demandante, prevista en numerosas normas reguladoras de la competencia judicial internacional, y que tal elección se haga conforme a sus intereses no puede calificarse per se como constitutiva de forum shopping, porque se llegaría al absurdo de considerar ilícita la utilización de una facultad prevista en la ley o exigir que el demandante escogiera el foro que le fuera menos favorable.

Pero tal decisión del demandante sí es constitutiva de forum shopping cuando las circunstancias concurrentes suponen que la elección del tribunal por aplicación del foro de conexión ha supuesto llevar el litigio a los tribunales del Estado que mantiene el vínculo más débil con el litigio, acumulando acciones contra demandados con domicilio en distintos Estados con la finalidad de sustraer al principal demandado (en tanto que su conducta perjudica en mayor medida al demandante) de los tribunales del Estado donde se encuentra su domicilio y cuya jurisprudencia (al menos la del tri- 
bunal que territorialmente correspondería a Acacia) le ha sido desfavorable, y llevarlo a un tribunal cuya jurisprudencia sabe que le es favorable [...]

Si un importante fabricante y distribuidor de productos supuestamente infractores de un dibujo o modelo comunitario puede ser demandado en cualquier Estado miembro en el que se produzca la venta, por mínima que sea, de alguno de estos productos, incluso por un vendedor al que el producto no le ha sido suministrado por dicho fabricante, mediante el subterfugio consistente en acumular la acción contra dicho fabricante a la acción contra ese vendedor y presentar la demanda en el tribunal del Estado del domicilio de este último, y mediante esa acción no se pretende únicamente la indemnización de los daños causados por el fabricante en el territorio del Estado en cuyos tribunales se presenta la demanda, sino que deje de actuar en todo el territorio de la Unión Europea, esto supondría que el único criterio atributivo de la competencia internacional sería la voluntad del demandante.

Esta estrategia procesal atenta no sólo contra el carácter principal del foro del domicilio del demandado y el carácter excepcional del foro de conexión del art. 6.1 del Reglamento 44/2001, sino también contra las más elementales exigencias de previsibilidad del foro que inspira la regulación del sistema de competencia judicial internacional de estos Reglamentos comunitarios».

ATS (Sala 1. ${ }^{a}$ ) de 8 de febrero de 2017 (rec. 1752/2014): suspensión de recurso de casación interpuesto por el banco predisponente y planteamiento de cuestión prejudicial comunitaria al TJUE en relación con el alcance de la nulidad contractual de vencimiento anticipado a causa del impago de una sola cuota de amortización mensual

Aureliano interpone, ante el Juzgado de lo Mercantil, una demanda de proceso ordinario a fin de que se declare la nulidad de determinadas condiciones generales de la contratación incluidas en el contrato de préstamo hipotecario concertado en el año 2008 con «NCG Banco, S. A.», por importe de 100.000 euros; en concreto, las relativas al tipo de interés aplicable (con cláusula suelo), imputación de gastos, intereses de demora y el vencimiento anticipado del crédito. El tenor literal de esta última cláusula es el siguiente: «6. ${ }^{a}$ bis. Resolución anticipada por la entidad de crédito. La Caja [el banco], sin necesidad de requerimiento previo, podrá dar por vencido el préstamo y exigir judicialmente la totalidad de la deuda, tanto 
de las cantidades vencidas como pendientes de vencer, con sus intereses, demoras, gastos y costas, en los siguientes casos: a) Falta de pago de cualquiera de los vencimientos de intereses o cuotas de amortización, incluidos todos los conceptos que la integran, solicitando expresamente las partes la constancia de este pacto en los libros del registro de la propiedad, según lo dispuesto en el art. 693 de la Ley 1/2000 [...] f) Por incumplimiento de cualquiera de las cláusulas del contrato».

La demanda es estimada en la instancia y en apelación. El banco demandado interpone entonces recurso de casación contra la SAP (Secc. 1. ${ }^{a}$ ) núm. 175/2014, de 14 de mayo (rec. 220/2014), en cuyo curso la Sala 1. ${ }^{a}$ del TS ha decidido suspender el proceso y plantear cuestión prejudicial comunitaria sobre la apreciación y los efectos de la declaración como abusiva de una cláusula de vencimiento anticipado a la luz de los distintos cauces procesales para suscitar esta declaración en el Derecho interno español y a todos los cuales no le son aplicables el art. 693.2 LEC.

En concreto, este importante auto acuerda literalmente: «Formular al Tribunal de Justicia de la Unión Europea, en el ámbito del art. 267 TFUE, las siguientes peticiones de decisión prejudicial, en interpretación del art. 6.1 de la Directiva 93/13/CEE del Consejo, de 5 de abril de 1993, sobre las cláusulas abusivas en los contratos celebrados con consumidores:

1. ${ }^{\circ}$ ¿Debe interpretarse el art. 6.1 de la Directiva 93/13/CEE en el sentido de que admite la posibilidad de que un tribunal nacional, al enjuiciar la abusividad de una cláusula de vencimiento anticipado incorporada en un contrato de préstamo hipotecario celebrado con un consumidor que prevé el vencimiento por impago de una cuota, además de otros supuestos de impago por más cuotas, aprecie la abusividad sólo del inciso o supuesto del impago de una cuota y mantenga la validez del pacto de vencimiento anticipado por impago de cuotas también previsto con carácter general en la cláusula, con independencia de que el juicio concreto de validez o abusividad deba diferirse al momento del ejercicio de la facultad?

2. ${ }^{\circ}$ ¿Tiene facultades un tribunal nacional, conforme a la Directiva 93/13/CEE, para — una vez declarada abusiva una cláusula de vencimiento anticipado de un contrato de préstamo o crédito con garantía hipotecaria - poder valorar que la aplicación supletoria de una norma de Derecho nacional, aunque determine el inicio o la continuación del proceso de ejecución contra el consumidor, resulta más favorable para el mismo que sobreseer dicho proceso especial de ejecución hipotecaria y permitir al acreedor instar la resolución del contrato de préstamo o crédito, o la reclamación de las cantidades debidas, y la subsiguiente ejecución de la sen- 
tencia condenatoria, sin las ventajas que la ejecución especial hipotecaria reconoce al consumidor?».

A raíz del dictado de este ATS muchas audiencias provinciales han acordado suspender los recursos que tienen pendientes de resolver relativos a cláusulas de vencimiento anticipado a la espera de que se pronuncie el TJUE (vid. el apartado Selección de otras resoluciones y actos en materia procesal de esta crónica).

ATS (Sala 1. ${ }^{a}$ en Pleno) de 15 de febrero de 2017 (rec. 1085/2016) y ATS (Sala 1. ${ }^{a}$ ) de 29 de marzo de 2017 (rec. 5/2017): conflicto negativo de competencia resuelto a favor del Juzgado de Violencia sobre la Mujer por la pendencia de proceso penal al tiempo de interposición de la demanda civil, en virtud de la perpetuatio iurisdictionis, aunque después se acordara el archivo o el sobreseimiento

El ATS resuelve el conflicto negativo de competencia planteado entre el Juzgado de Instrucción núm. 2 de Guadalajara, con competencias sobre violencia sobre la mujer, y el Juzgado de Primera Instancia núm. 6 de Alcalá de Henares para conocer de una demanda de demanda de medidas previas de carácter paterno-filial en relación con un hijo común nacido de una relación more uxorio. A este Juzgado había acudido el padre para que se establecieran medidas paterno-filiales, que, por su parte, también pidió la madre ante un Juzgado de Violencia sobre la Mujer de Jaén, pese a que, al tiempo de interposición de esta primera demanda, existía una causa penal abierta ante el Juzgado de Violencia sobre la Mujer de Guadalajara. Habiéndose inhibido sucesivamente el JVM de Jaén y el JPI de Alcalá de Henares, el JVM de Guadalajara se declara también falto de competencia por haber acordado en febrero de 2016 el sobreseimiento y archivo de la causa penal.

El ATS resuelve en favor del JVM, en virtud de la seguridad jurídica que ofrece la perpetuatio iuridictionis, en el mismo sentido en el que postula la Circular de la Fiscalía núm. 4/2005, relativa a los criterios de aplicación de la Ley Orgánica de Medidas de Protección Integral contra la Violencia de Género.

«El principio de seguridad jurídica (art. 9.3 CE) determina que, una vez fijada la competencia objetiva, territorial y funcional al iniciarse el proceso, no surtirán efecto para modificar la competencia los posteriores cambios de las condiciones fácticas y jurídicas que se produzcan. Consecuen- 
cia de ello es que si a la fecha de interposición de la demanda o petición inicial del proceso civil estaba vigente el proceso penal, la competencia corresponde al Juzgado de Violencia sobre la Mujer aunque el procedimiento haya sido objeto de sobreseimiento y archivado al momento de recepción del auto de inhibición. Tal criterio permite sentar unas bases ciertas y objetivas, siendo plenamente conforme con el principio de la perpetuatio jurisdictioni contemplado en el art. 411 LEC, con el derecho al juez ordinario predeterminado por la ley que consagra el art. 24.2 de la Constitución y con el principio de economía procesal, elemento este último esencial en una materia como es el derecho de familia. En consecuencia, la competencia para el conocimiento del asunto le corresponde al Juzgado de Instrucción núm. 2 de Guadalajara, con competencias sobre violencia sobre la mujer, al concurrir al momento de interposición de las demandas civiles el supuesto previsto en el apartado 3 del art. 87 ter de la Ley Orgánica del Poder Judicial».

Este criterio ha sido aplicado poco después en el ATS (Sala 1.a) de 29 de marzo de 2017 (rec. 5/2017), si bien con la particularidad de devolver la causa al «Juzgado de Violencia sobre la Mujer núm. 1 de Arganda del Rey» para que, como órgano que conocía de la causa penal al tiempo de interposición de la demanda (en este caso, de reclamación de la paternidad), se pronuncie sobre su competencia, al haber intervenido en el conflicto negativo antecedente.

STS (Sala 1. ${ }^{a}$ en Pleno) núm. 23/2017, de 24 de febrero (rec. 740/2014), y STS (Sala 1. ${ }^{a}$ ) núm. 345/2017, de 1 de junio (rec. 393/2015): aplicación de la nuena doctrina del TS sobre la devolución de las cantidades indebidamente cobradas en virtud de una cláusula suelo declarada nula, más sus intereses legales

En el caso de la primera STS, el recurso de casación se dirige, sin éxito, contra la SAP de Barcelona (Secc. 15. ${ }^{a}$ ) de 16 de diciembre (rec. 719/2012), estimatoria de la demanda. La entidad BBVA alega la infracción del art. 1.303 CC y de la jurisprudencia que limita temporalmente los efectos de la declaración de nulidad de las cláusulas «suelo» por falta de transparencia, invocando, al efecto, la STS (Sala 1.a) núm. 241/2013, de 9 de mayo (rec. 485/2013).

Durante la tramitación del recurso, a raíz de la STJUE de 21 de diciembre de 2016 (asuntos acumulados C-154/15, C-307/15 y C-308/15, caso 
Gutiérrez Naranjo), se concedió a las partes un trámite de alegaciones. La parte recurrida adujo la plena aplicación de la doctrina de esta sentencia, mientras que la recurrente - en contra de lo que había sostenido en las anteriores instancias - alegó la existencia de cosa juzgada, apreciable incluso de oficio, en relación con la STS núm. 241/2013, de 9 de mayo, y, subsidiariamente, solicitó el planteamiento de dos cuestiones prejudiciales ante el TJUE.

Pues bien, esta STS niega, una vez más, que opere la eficacia negativa o excluyente (la prohibición de bis in idem) de la cosa juzgada material de la STS (Sala 1. ${ }^{a}$ ) núm. 241/2016, por falta de identidades subjetiva y objetiva. Ni la cláusula impugnada tiene el mismo tenor ni, aunque el BBVA haya sido parte en ambos procesos, existe identidad subjetiva.

Sobre esto último sostiene la STS que «aunque BBVA haya sido parte en ambos procedimientos, en el que ahora nos ocupa lo ha sido por una doble sucesión procesal al adquirir a la entidad (Unnim), en la que, a su vez, se había fusionado la acreedora inicial (Caixa d'Estalvis Comarcal de Manlleu). Y no fue quien predispuso e impuso en el contrato de préstamo la cláusula litigiosa. En principio, en caso de sucesión procesal podría darse la identidad subjetiva entre causahabientes a que se refiere el art. 222.3 LEC, pero en supuestos como el presente, de condiciones generales de la contratación, no puede apreciarse tal identidad si el predisponente no es el mismo ni fue quien utilizó la cláusula que se ha declarado nula en pronunciamiento firme no discutido ya en este recurso de casación.

Conforme al art. 17.1 LEC, la transmisión del objeto litigioso puede conllevar la sucesión procesal, que tiene como consecuencia, si se cumplen los requisitos legales para ello, que el adquirente (BBVA) ocupe la situación procesal que tenía el transmitente (Unnim de manera próxima y Caixa de Manlleu de manera remota). Lo que supone que BBVA se coloque en la posición procesal que ocupaba inicialmente la mencionada Caixa como predisponente de una determinada y concreta condición general de la contratación, no de otra diferente que utilizaba el adquirente en otros contratos y como entidad bancaria distinta».

Además, respecto de la falta de identidad objetiva, el TS sostiene, también una vez más, que la sentencia dictada en proceso colectivo de cesación no impide la sustanciación de un proceso individual de nulidad de la cláusula general: «Para la apreciación de cosa juzgada, entre acciones colectivas y acciones individuales no existe identidad objetiva, puesto que tienen "objetos y efectos jurídicos diferentes"». 
Por otro lado, rechaza también el TS que proceda plantear cuestión prejudicial comunitaria sobre los criterios de exclusión o limitación del efecto restitutorio de cantidades que, en ausencia de esa condición general abusiva, no hubieran debido pagarse, por la claridad que arroja sobre este punto la STJUE de 21 de diciembre de 2016: «En la STJUE de 21 de diciembre de 2016 queda claro que cualquier limitación temporal de los efectos restitutorios tras la declaración de abusividad de la cláusula litigiosa infringe el art. 6.1 de la Directiva 93/13/CEE y que la consecuente obligación de devolución de las cantidades indebidamente cobradas no permite matiz alguno, so pena de no garantizar los derechos del consumidor afectado e infringir el art. 7.1 de la misma Directiva».

Por último, la Sala 1. ${ }^{a}$ abandona el criterio que sentó en su STS (Sala 1. ${ }^{a}$ ) núm. 241/2013, de 9 de mayo, sobre los efectos temporalmente limitados de la nulidad de la cláusula suelo, para defender la primacía del Derecho comunitario y de su interpretación conforme a la jurisprudencia vinculante y obligatoria del TJUE:

«En consecuencia, procede modificar la jurisprudencia de esta Sala sobre los efectos retroactivos de la declaración de nulidad de la denominada cláusula suelo, toda vez que la citada STJUE de 21 de diciembre de 2016 ha considerado que: a) La limitación en el tiempo de los efectos jurídicos derivados de la declaración de nulidad de las cláusulas suelo, que el Tribunal Supremo acordó en la Sentencia de 9 de mayo de 2013, se opone al art. 6.1 de la Directiva 93/13/CEE y equivale a privar, con carácter general, a todo consumidor que haya celebrado antes de aquella fecha un contrato de préstamo hipotecario que contenga una cláusula de ese tipo del derecho a obtener la restitución íntegra de las cantidades que haya abonado indebidamente a la entidad bancaria en virtud de la cláusula suelo durante el período anterior al 9 de mayo de 2013. b) Dicha jurisprudencia nacional sólo permite garantizar una protección limitada a los consumidores que hayan celebrado un contrato de préstamo hipotecario que contenga una cláusula suelo con anterioridad a la fecha del pronunciamiento de la resolución judicial mediante la que se declaró dicho carácter abusivo, y tal protección resulta incompleta e insuficiente y no constituye un medio adecuado y eficaz para que cese el uso de dicha cláusula, en contra de lo que establece el art. 7.1 de la Directiva 93/13/CEE [...] En su virtud, puesto que la sentencia recurrida se ajustaba a lo que ha venido a resolver posteriormente la STJUE de 21 de diciembre de 2016, el recurso de casación ha de ser desestimado, ya que, aunque en su momento lo planteado en dicho recurso era acorde con la jurisprudencia de esta Sala, no lo es una 
vez que la misma ha de acomodarse a lo resuelto por el Tribunal de Justicia de la Unión».

Esta doctrina se reitera en la segunda STS que nos ocupa, de fecha 1 de junio de 2017, que estima el recurso de casación interpuesto por el consumidor contra la SAP de Bizkaia que se atuvo a la limitación temporal que impuso el TS a los efectos de la nulidad de una cláusula suelo en su STS de 9 de mayo de 2013 y, en su virtud, el TS reafirma el cambio de doctrina jurisprudencial y, en el caso planteado, desestima el recurso de apelación y confirma la sentencia del Juzgado que estimó íntegramente la demanda.

\section{STS (Sala 1. ${ }^{\text {a) }}$ núm. 157/2017, de 7 de marzo (rec. 1874/2016): nulidad de la sentencia de apelación en la que se revoca el régimen de guarda y custodia del hijo menor por no haber sido explorado}

Acordada - en la instancia - en favor del padre la medida de guarda y custodia de la hija menor en un proceso de divorcio, la AP de Bizkaia la revoca para establecer, en su lugar, un régimen de guarda y custodia compartida. Contra esta sentencia el padre interpone recurso extraordinario por infracción procesal en el que denuncia la infracción del art. 475 LEC, por no haberse practicado la exploración de la menor ni la correspondiente prueba pericial por parte del equipo psicosocial judicial.

Empezando por la alegación de esta última ausencia, el TS considera que la falta de emisión de esta prueba pericial «siendo conveniente en estos casos, no se constituye en requisito imprescindible en el art. 92.6 y 9 CC».

En cambio, «en relación a la falta de exploración de la hija, esta Sala se ha pronunciado con reiteración respecto a la necesidad de ser oído el menor en los procedimientos que directamente les afectan. La Sentencia de 20 de octubre de 2014 establece lo siguiente: "La aparente contradicción entre el Código Civil y la Ley de Enjuiciamiento Civil viene a ser aclarada por la Ley del Menor y por el Convenio sobre Derechos del Niño, en el sentido de que cuando la edad y madurez del menor hagan presumir que tiene suficiente juicio y, en todo caso, los mayores de doce años, habrán de ser ó́dos en los procedimientos judiciales en los que se resuelva sobre su guarda y custodia, sin que la parte pueda renunciar a la proposición de dicha prueba, debiendo acordarla, en su caso, el juez de oficio. En este mismo sentido la Sentencia del Tribunal Constitucional de 6 de junio de 2005.

Para que el juez o tribunal pueda decidir no practicar la audición, en aras al interés del menor, será preciso que lo resuelva de forma motivada". 
Al día de hoy se desconoce la opinión de la menor, a la que no se ha dado la oportunidad de ser escuchada; opinión que es especialmente relevante en atención a las circunstancias apuntadas de convivencia exclusiva desde los siete años con su padre, y a la edad de la hija».

En consecuencia, la Sala 1. estima el recurso y manda retrotraer las actuaciones «al momento anterior a dictar sentencia para que antes de resolver sobre la guarda y custodia de la hija se oiga a esta de forma adecuada a su situación y a su desarrollo evolutivo, cuidando de preservar su intimidad, resolviendo en su vista sin tener en cuenta el argumento de no haber existido oposición del recurrente a la solicitud de guarda y custodia compartida interesada por la madre».

ATS (Sala 1. ${ }^{a}$ ) de 15 de marzo de 2017 (rec. 329/2013): los tribunales nacionales no tienen facultades moderadoras de los derechos arancelarios de procurador, pese a que se impugne su tasación por incompatibilidad con el Derecho europeo

Este auto pone fin a un incidente de impugnación de tasación de costas por el doble motivo de ser excesivos los honorarios de letrado y ser indebidos los derechos del procurador. Las alegaciones que sustentaban la impugnación de esta última partida era que, de un lado, se habían incluido los mismos derechos en esta tasación y en la de las costas del previo recurso de apelación, y, de otro lado, y más importante, en que procedía aplicar criterios de moderación y no aplicar automáticamente la tabla de aranceles de los procuradores por su incompatibilidad con la normativa europea en materia de libertad de servicios en el mercado interior.

En su decreto, el secretario judicial modera y reduce los honorarios de letrado a la vista del informe colegial, y en cuanto a los derechos de procurador, estima en parte la impugnación del condenado y, acogiendo el primer motivo de impugnación, reduce a la mitad los derechos del procurador, para que queden circunscritos a los que corresponden al recurso extraordinario por infracción procesal. Contra este decreto ambas partes interponen recurso de revisión que son resueltos en este auto cuyo interés radica en el examen de la fijación de los derechos de procurador.

La Sala 1. ${ }^{a}$ del TS recuerda que, conforme a varios pronunciamientos anteriores, no es posible eludir la aplicación del arancel de los derechos de los procuradores de los tribunales regulado en el Real Decreto 1373/2003, de 7 de noviembre. 
Se recuerda así que ya la STC 108/2013, de 6 de mayo, desestimó aplicar el «principio de proporcionalidad» a la determinación de los derechos de procurador en una tasación de costas proveniente del orden contencioso-administrativo y anuló un auto de la Sala 3. ${ }^{a}$ del TS por la interpretación contra legem que había efectuado de la disposición adicional única del RD-ley $5 / 2010$, por la que se incluyó una limitación máxima a los derechos de procurador. Al decir de esta STC, el órgano judicial no podía «inaplicar una norma reglamentaria sin expresar razonamientos sobre su ilegalidad y sin que nadie lo haya impugnado».

De otro lado, tampoco es posible basar la pretendida moderación de los derechos de procurador en la normativa comunitaria relativa a la libre competencia después de lo establecido en la STJUE de 8 de diciembre de 2016 (asuntos C-532/15 y C-538/15), a saber: «El art. 101 TFUE, en relación con el art. 4 TUE, apartado 3, debe interpretarse en el sentido de que no se opone a una normativa nacional, como la controvertida en el litigio principal, que somete los honorarios de los procuradores a un arancel que sólo puede alterarse en un 12 por 100 al alza o a la baja, habiendo de limitarse los órganos jurisdiccionales nacionales a verificar su aplicación estricta, sin poder apartarse, en circunstancias excepcionales, de los límites fijados en dicho arancel».

Esta STJUE, sin embargo, no se pronunció - por carecer de competencia - sobre la posible compatibilidad del arancel de procuradores con la Directiva 2006/123, relativa a la libertad de servicios en el mercado interior, al no haber razonado suficientemente el órgano remitente la conexión de los litigios con el derecho de la Unión. Y la Sala 1. a del TS pasa por encima de la cuestión en esta sentencia, al no haberse suscitado la disconformidad de la normativa española en materia de aranceles de procurador con la Directiva 2006/123. Directiva que, en lo que ahora importa, obliga a los Estados a evaluar y a depurar la existencia de tarifas obligatorias mínimas impuestas para la prestación de un servicio, salvo que estén justificadas por una razón imperiosa de interés general y sean proporcionales y adecuadas para garantizar el objetivo que se persigue con ellas [art. 15.2.g) y 15.3.b) y c)].

Soslayada esta cuestión en la STS que nos ocupa, concluye la Sala 1. ${ }^{a}$ que «la consecuencia de lo expuesto es que la pretensión de Inmobiliaria Colonial, S. A., de que la Sala reduzca el importe de los derechos del procurador, resultantes de la aplicación automática del arancel, hasta obtener la cantidad que considera justa, razonable y proporcionada al trabajo efectivamente realizado, no es admisible. Los tribunales, en el caso de conde- 
na en costas, no pueden moderar los derechos de los procuradores establecidos normativamente en sus aranceles, ni pueden fijar estos derechos por comparación con los honorarios de otros profesionales».

El problema de fondo que plantea la fijación de derechos arancelarios y la propia justificación de la figura del procurador, que el legislador español ha pretendido atajar mediante diversas reformas procesales que le han añadido más funciones, sigue pendiente de ser tratado en su real magnitud. En la reciente Comunicación de la Comisión de 10 de enero de 2017 al Parlamento Europeo, al Consejo, al Comité Económico y Social Europeo y al Comité de las Regiones, relativa a las recomendaciones para la reforma de la regulación de los servicios profesionales [COM (2016) 820 final], se ha puesto de manifiesto que España, de entrada, no ha comunicado su preceptivo Plan de Acción Nacional (PAN) que estaba obligado a presentar en materia de servicios profesionales, y en lo que hace concretamente a procuradores y abogados, se recoge como recomendación que «España necesita examinar el alcance de las actividades reservadas a los procuradores y, en particular, si determinadas actividades como la representación técnica o la comunicación de documentos a los tribunales puede compartirse con los abogados. España debería emitir también directrices e instrucciones claras sobre la colegiación de los abogados después de la entrada en vigor del nuevo sistema de cualificación».

ATS (Sala 1. ${ }^{a}$ en Pleno) de 4 de abril de 2017 (rec. 7/2017), ATS (Sala 1. ${ }^{a}$ ) de 19 de abril de 2017 (rec. 12/2017) y ATS (Sala 1. ${ }^{a}$ ) de 10 de mayo de 2017 (rec. 25/2017): no cabe revisar una sentencia firme a causa de un cambio de la jurisprudencia posterior, pese a que el cambio venga propiciado por una sentencia del TJUE

El ATC de 4 de abril de 2017, dictado por la Sala 1. ${ }^{a}$ constituida en Pleno, ha sido el primero en cerrar la vía de la revisión a los miles de consumidores y usuarios a los que, en sentencia firme (en este caso, dictada en octubre de 2016 por un Juzgado de Primera Instancia), se les aplicó la limitación de los efectos retroactivos de la nulidad de una cláusula suelo de acuerdo con la doctrina sentada en la STS (Sala 1. ${ }^{a}$ ) núm. 241/2013, de 9 de mayo (rec. 485/2013), que los limitó a los pagos realizados a partir de la fecha de publicación de la propia sentencia. Dado que esta jurisprudencia ha sido declarada no conforme con la Directiva 93/13/CEE sobre cláusulas abusivas, por la importante STJUE de 21 de diciembre de 2016 (asun- 
tos acumulados C-154/15, C-307/15 y C-308/15, caso Gutiérrez Naranjo), uno de esos afectados intenta la revisión de su sentencia firme a fin de que se rescinda y deje sin efecto para poder verse libre de la cosa juzgada material y plantear ex novo una demanda de reclamación de todas las cantidades indebidamente pagadas en virtud de la cláusula nula.

Este importante auto, al que han seguido los posteriores AATS de 19 de abril y de 10 de mayo de 2017, se opone con rotundidad a cualquier intento de revisar una sentencia firme por este motivo. En sus varios y extensos fundamentos el Pleno de la Sala $1 .^{a}$ desagrana todas las razones, a saber:

1. ${ }^{\circ} \quad$ Sigue valiendo la jurisprudencia según la cual una sentencia posterior que suponga un cambio de doctrina no tiene la consideración de «documento recobrado» en el que pueda fundarse una demanda de revisión al amparo del art. 510.1.1. ${ }^{\circ}$ LEC.

2. Lo anterior no cambia por el hecho de que la sentencia posterior sea del TJUE: «Una sentencia del TJUE de fecha posterior a la sentencia cuya revisión se insta no es un documento que permita la revisión de una sentencia firme conforme al art. 510.1.1. ${ }^{\circ}$ de la Ley de Enjuiciamiento Civil y que ha de prevalecer el efecto de cosa juzgada de la sentencia firme dictada con anterioridad». El TS recuerda que el propio TJUE en Sentencia (Sala 1. ${ }^{a}$ ) de 16 de marzo de 2006 (asunto C-234/04, caso Kapferer) sostuvo, «tras resaltar la importancia de la cosa juzgada en un sistema presidido por el valor de la seguridad jurídica, que el Derecho comunitario no impone la revisión de las sentencias firmes cuando tal posibilidad no está prevista en la normativa procesal nacional». El TS añade que «el legislador español ha tenido ocasión reciente de hacerlo, y, sin embargo, únicamente ha previsto un mecanismo especial de revisión cuando se trata de una sentencia del Tribunal Europeo de Derechos Humanos (apartado 2 del art. 510 LEC, en redacción dada por la Ley Orgánica 7/2015, de 21 de julio), pero no ha incluido igual solución para las sentencias del TJUE».

3. Ni siquiera los cambios de jurisprudencia del TS o la del TC produce una quiebra en «el respeto a la institución de la cosa juzgada que impide reabrir procesos finalizados por sentencia firme (cosa juzgada formal) y que se abra un nuevo proceso sobre el mismo objeto ya juzgado y resuelto por sentencia firme (cosa juzgada material, en su aspecto negativo)».

4. ${ }^{\circ}$ El propio TJUE en varias de sus resoluciones [SSTJUE de 21 de diciembre de 2016, de 26 de enero de 2017 (asunto C-421-14, caso Banco Primus) y, antes, en la de 6 de octubre de 2009 (asunto C-40/08, caso Asturcom Telecomunicaciones)] ha puesto en valor la cosa juzgada material: 
«Tanto en el ordenamiento jurídico de la Unión como en los ordenamientos jurídicos nacionales [...] es necesario que no puedan impugnarse las resoluciones judiciales que hayan adquirido firmeza tras haberse agotado las vías de recurso disponibles o haber expirado los plazos previstos para el ejercicio de tales recursos».

5. En suma, «no es posible obtener la revisión de una sentencia firme por el hecho de que una sentencia posterior establezca una jurisprudencia que sea incompatible con los argumentos que fundamentan el fallo de la sentencia anterior [...] Teniendo en cuenta los principios en los que se basa el sistema jurisdiccional nacional, tales como la protección del derecho de defensa, el principio de seguridad jurídica y el buen desarrollo del procedimiento, la exclusión de la rescisión de sentencias firmes por contradecir lo declarado posteriormente en una sentencia del TJUE no puede considerarse contrario al principio de efectividad del Derecho de la Unión Europea».

Este auto ha marcado el camino para que, con posterioridad, la Sala 1. ${ }^{a}$ haya reiterado que una sentencia del TJUE de fecha posterior a la sentencia cuya revisión se insta no constituye un motivo de revisión y que ha de prevalecer el efecto de cosa juzgada de la sentencia firme dictada con anterioridad.

STS (Sala 1. ${ }^{a}$ ) núm. 222/2017, de 5 de abril (rec. 542/2015): legitimación activa de la tomadora de seguro de vida e incapacidad permanente absoluta para exigir el cumplimiento del contrato del que es beneficiaria la entidad bancaria que predispuso su contratación vinculada con un préstamo hipotecario

Eulalia, en su condición de tomadora, interpuso demanda contra la compañía aseguradora «Rural Vida, S. A.» para que fuera condenada a cumplir el seguro de incapacidad permanente absoluta suscrito por ella y se le pagasen las cantidades convenidas. Tras oponer la compañía demandada la falta de legitimación activa de la tomadora, en la audiencia previa la demandante pretendió precisar «que no se reclamaba el pago para la propia demandante, sino a cuenta de la misma» (sic), lo que fue rechazado por considerarse una alteración sustancial de la demanda.

Tanto en primera instancia como en apelación los tribunales han desestimado la demanda por falta de legitimación activa de la demandante, que no es la beneficiaria, sino la tomadora del seguro. Contra la sentencia de apelación Eulalia interpone recurso extraordinario por infracción procesal al amparo de los núms. 1, 3 y 4 del art. 469 LEC, por infracción de los 
arts. 10 LEC y 24.1 CE, por negarse la legitimación activa de la demandante $y$, en su consecuencia, vulnerarse su derecho a la tutela judicial efectiva.

Pues bien, estamos ante uno de los muchos supuestos en los que las partes y el TS confunden la legitimación procesal, regulada en el art. 10 LEC y basada en las assertationes de la demanda, y la legitimación material, regida - normalmente- por el Derecho sustantivo y determinante no de la condición de parte («procesal legítima», en los términos del art. 10 LEC) — como la primera—, sino del signo estimatorio o desestimatorio de la demanda. Es preciso insistir en ello: cada vez que en el proceso se tiene por parte a quienes, por las manifestaciones de la demanda, se atribuyen la subjetividad de la relación jurídica u objeto litigioso, pese a que después resulten no ser tales o no ostentar una condición jurídica idónea para que se conceda la concreta tutela, no hay infracción del art. 10 LEC. Al contrario, se ha dado cumplimiento al art. 10 LEC (pues parte han sido) y la cuestión será ya otra: el examen de su legitimación material, esto es, si se encuentran - $\mathrm{O}$ no- en el círculo de sujetos a los que el Derecho coloca en las posiciones legitimantes que fundamentan la concesión a su favor o en su contra de la concreta tutela jurisdiccional pedida.

Yerra, pues, el TS cuando incardina las cuestiones de legitimación material en el recurso extraordinario por infracción procesal que luego termina estimando por razones que nada tienen que ver con la condición de parte procesal ni con la infracción de normas y garantías procesales, sino con resolver jurídicamente el thema decidendi en cuanto al fondo, esto es, con la consistencia jurídica de la posición del sujeto y la cuestión de si es titular - o no- de un derecho subjetivo privado o de un interés jurídico equivalente que sustente la concesión a su favor de lo pretendido. Patentizan este error las razones que ofrece el STS para estimar la infracción del art. 10 LEC en este supuesto:

$\ll 1 .^{a} \quad$ Estando ante un seguro de vida con cobertura de invalidez vinculado a un préstamo hipotecario, que no se niega fuera suscrito con una aseguradora del mismo grupo que la entidad designada como primera beneficiaria, es indudable que al producirse el siniestro objeto de cobertura - reconocimiento de la invalidez-, y ante la inactividad de la entidad prestamista beneficiaria, la asegurada/tomadora, demandante y hoy recurrente, tenía legitimación activa para interesar el cumplimiento del seguro en vigor y, por tanto, para reclamar de su aseguradora el cumplimiento de sus obligaciones contractuales, entre ellas, y como principal, el pago de la suma asegurada, sin perjuicio de respetar los derechos de la entidad prestamista beneficiaria. 
2. $\quad$ Esto fue lo que aconteció, pues como resulta de las peticiones de la demanda (la demandante destacó en negrita la pretensión de cumplimiento) y de los preceptos invocados en su fundamentación jurídica (arts. 1.088, 1.089, 1.091, 1.101 y 1.124 CC, todos ellos relativos a la fuerza vinculante del contrato denegado y a la responsabilidad contractual por incumplimiento), la acción principalmente ejercitada fue la de cumplimiento contractual, para la que la demandante se encontraba legitimada como parte del contrato de seguro y como titular del interés asegurado. No admitir tal legitimación podría dar lugar a que, por la sola inactividad de la entidad prestamista en cuanto beneficiaria del seguro y su actividad en cuanto prestamista frente al prestatario, este tuviera que seguir amortizando el préstamo, que es precisamente aquello frente a lo que le protege el seguro cuya prima corre a su cargo.

3. ${ }^{a} \quad$ En definitiva, el seguro litigioso respondía a un interés compartido por la tomadora/asegurada demandante y la entidad de crédito prestamista: el de la primera, quedar liberada de su obligación de devolver el préstamo si se producía el siniestro, y el de la segunda, garantizarse la devolución del préstamo si no lo devolvía la prestataria en caso de muerte o invalidez. Pero en cualquier caso es más que evidente el interés legítimo de la asegurada, y en caso de muerte el de quienes le sucedan en sus derechos y obligaciones, en que el seguro responda a la causa por la que se contrató, se haga efectivo y, en consecuencia, se la libere de su obligación de devolver el préstamo por quedar entonces la obligación de devolver el capital pendiente a cargo de la aseguradora. Entenderlo de otra forma equivale a poder dejar inermes al asegurado o a su familia en un trance especialmente difícil que el asegurado quiso evitar precisamente mediante la concertación del seguro y el pago de la prima correspondiente, cuya contrapartida no puede ser otra que la respuesta de la aseguradora entregando el dinero a la prestamista designada como primera beneficiaria pero para saldar la deuda que aparezca en la cuenta del asegurado, lo que demuestra que también este es beneficiario desde un punto de vista sustancial o material y no puramente formal.

4. ${ }^{a} \quad$ Tanto la sentencia de primera instancia como la de apelación negaron la legitimación activa de la demandante hoy recurrente por haber solicitado el cobro para sí y no para la primera beneficiaria. Sin embargo, no hay ninguna base razonable para entender que la demandante pretendiera soslayar los derechos de la entidad prestamista intentando el cobro para sí del capital asegurado, pues cualquier duda a que pudiera dar lugar la literalidad de las peticiones de la demanda quedó disipada por la propia parte 
demandante en el acto de la audiencia previa por el cauce del art. 426.2 LEC. No hubo, pues, una mutatio libelli prohibida por el art. 412 LEC, como considera la sentencia recurrida, sino una aclaración conducente a delimitar el objeto del proceso en función de lo alegado en la contestación a la demanda.

5. En consecuencia, no admitir dicha aclaración — con base en una interpretación excesivamente formalista del art. 426 LEC- causó una evidente indefensión a la parte demandante hoy recurrente desde el momento en que la razón decisoria de las sentencias de ambas instancias fue que la demandante no podía reclamar el pago para sí del capital asegurado».

\section{STS (Sala 1. ${ }^{\text {a }) ~ n u ́ m . ~ 251 / 2017, ~ d e ~} 25$ de abril (rec. 2981/2017): validez de una cláusula de venta extrajudicial de bien hipotecado por no producir por sí misma desequilibrio contractual al no haberse alegado la existencia de cláusulas materiales abusivas}

Tras dejar impagadas varias mensualidades de un préstamo hipotecario con cláusula de «venta extrajudicial», el banco inició los trámites de la venta notarial al tiempo que el prestatario presentó demanda de nulidad de la cláusula de venta extrajudicial inserta en el préstamo hipotecario. Desestimada en la instancia, la AP de Valencia estimó el recurso de apelación y declaró la nulidad de la cláusula, que ahora es recurrida en casación.

El banco predisponente denuncia la infracción del apartado 3 del art. 82 TRLCU en relación con el apartado 1, porque la sentencia no tiene en cuenta, para enjuiciar la abusividad de la cláusula, las demás cláusulas del contrato que deberían tutelarse dentro del procedimiento extrajudicial del art. $129 \mathrm{LH}$ y, en consecuencia, ha apreciado debidamente un desequilibrio contractual que no concurre. El recurso se estima y, junto con la precedente STS (Sala 1. ${ }^{a}$ ) núm. 483/2016, de 14 de julio (rec. 1668/2014), constituye doctrinal jurisprudencial.

La STS comienza reiterando que, «conforme a la jurisprudencia del Tribunal de Justicia de la Unión Europea, una cláusula que permita al profesional que contrata con el consumidor acudir a la ejecución extrajudicial no es en sí misma abusiva [SSTJUE de 10 de septiembre de 2014 (asunto C-34/13 , Ku?ionová) y 25 de junio de 2015 (asunto C-32/2014, Sugár)]».

El eventual carácter abusivo de la cláusula que permitía acudir al procedimiento de venta extrajudicial del art. 129 LH dependía del contenido de la regulación de esta norma. Bajo la aplicación de la regulación origi- 
naria no se preveía el control de las cláusulas abusivas, mientras que tras las reformas introducidas por la Ley $1 / 2013$, de 14 de mayo, y sobre todo la Ley 19/2015, de 13 de julio, sí [...] Ahora bien, no podemos perder de vista que estamos ante una acción individual en la que se pretende la declaración de nulidad de una cláusula en la que se conviene la posibilidad de acudir a la venta extrajudicial, y que el juicio de abusividad es concreto y debe realizarse conforme a las circunstancias del caso.

En nuestro caso, se pide la nulidad de la estipulación $11 .^{a}$, pero no se aducen por el peticionario las cláusulas que habría podido invocar como abusivas, y por ello nulas, para suspender la ejecución y oponerse a ella, y que no pudieron serlo. Que es lo que pondría en evidencia la limitación efectiva y concreta de los derechos del consumidor que le habría ocasionado la cláusula controvertida [...] Por eso, en nuestro caso, como no se mencionan por la demandante la existencia de estas cláusulas abusivas que no han podido invocarse, debe rechazarse la apreciación de que haya existido una abusividad real».

STS (Sala 1. ${ }^{a}$ ) núm. 320/2017, de 23 de mayo (rec. 837/2015): constitucionalidad y validez del procedimiento no jurisdiccional de venta extrajudicial por suficiencia del rango legal prestado por la LEC

Ha llegado a la Sala 1. ${ }^{\text {a }}$ del TS un recurso que plantea la nulidad del muy utilizado procedimiento de venta extrajudicial de inmueble a través del cual —en el caso planteado- se enajenó el bien hipotecado en tercera subasta notarial celebrada sin sujeción a tipo y por un valor inferior al límite mínimo del 60 por 100 que marca la LEC para las ejecuciones hipotecarias. Es importante hacer notar que el recurrente no tiene la consideración de consumidor y que el inmueble no constituye vivienda familiar.

La pretensión de nulidad del procedimiento ha sido desestimada en las dos instancias y ahora se recurre en casación por: 1) haberse seguido un procedimiento reglamentario de ejecución extrajudicial contrario a la exclusividad e integridad de jurisdicción, a la tutela judicial efectiva y al principio de legalidad, y 2) por no respetar los arts. 234 y $236 \mathrm{RH}$ - entonces vigentes- los valores mínimos de adjudicación establecidos en la LEC. Ambos motivos son desestimados en esta importante sentencia que, junto con la STS (Sala 1. a) núm. 373/2009, de 25 de mayo (rec. 922/2001), constituye jurisprudencia y produce un cambio sustancial en la materia a raíz de las modificaciones legislativas sobrevenidas. 
«Es cierto que las sentencias de esta sala, citadas por la recurrente, han mantenido el procedimiento extrajudicial como derogado por la Constitución de 1978 [...] La sentencia de 25 de mayo de 2009, que resume la doctrina declarada en la materia, insiste en la inconstitucionalidad, pero matiza que esa doctrina ha recaído "en supuestos como el presente, referidos a actuaciones anteriores a la entrada en vigor de la nueva Ley de Enjuiciamiento Civil de 7 de enero de 2000" [...]

La publicación de la LEC 2000 vino a terciar en la polémica, pues pretendió superar las objeciones que se hacían al procedimiento extrajudicial y, lo que es más relevante para la decisión del motivo del recurso, se trata ya de norma postconstitucional [...]

Consecuencia de lo anteriormente expuesto es que nuestras Audiencias Provinciales, cuando se han planteado la cuestión sobre la que decide la sentencia recurrida, ofrezcan la misma respuesta: se trata de la norma actualmente vigente y no puede ser ignorada por una doctrina anterior del Tribunal Supremo referente a supuestos recogidos por normas anteriores a la promulgación de la Constitución. La nueva disposición legal sólo podrá ser declarada inconstitucional por el Tribunal Constitucional y no lo ha hecho.

La Sentencia del pleno 483/2016, de 14 de julio, aunque trata este procedimiento desde otro punto de vista —el carácter abusivo de la cláusula que prevé la posibilidad de venta extrajudicial — analiza la jurisprudencia del TJUE sobre este tipo de procesos extrajudiciales sin poner en duda la validez ni la constitucionalidad del actual art. 129 LH. La Sentencia $251 / 2017$, de 25 de abril, en un supuesto similar al anterior, se ha pronunciado en los mismos términos.

Enlazando con la anterior consideración, es preciso poner de relieve que es esta inconstitucionalidad la pretensión de la parte actora en su demanda, y no la nulidad de la cláusula contractual que ha permitido que la entidad acreedora acuda al procedimiento previsto en el art. $129 \mathrm{LH}$.

STS (Sala 1. ${ }^{a}$ en Pleno) núm. 324/2017, de 24 de mayo (rec. 197/2015): subsistencia de la capacidad para ser parte y procesal de sociedad disuelta y liquidada a los efectos del reconocimiento judicial de deudas sobrevenidas

La SAP de Valencia recurrida resolvió, con estimación del recurso, desestimar íntegramente la demanda por falta de personalidad o de capa- 
cidad de ser parte de la demandada, una sociedad que registralmente había quedado ya disuelta y liquidada. La sentencia es recurrida en casación por la demandante, que basa su recurso en la «infracción de art. 6.1.3 de la Ley de Enjuiciamiento Civil, el art. 228 del Código de Comercio, los arts. 238 a 248 del Reglamento del Registro Mercantil, los arts. 109 y 123 de la Ley de Sociedades de Responsabilidad Limitada, con sus concordantes, el art. 121 LSRL y los arts. 274.1, 277.2 y 280.a), y la disposición transitoria sexta, 2, de la Ley de Sociedades Anónimas».

Este recurso da ocasión a que el TS fije, de una vez, doctrina sobre la extinción o la perpetuación de la personalidad jurídica en general - $\mathrm{y}$ procesal en particular - de una sociedad extinta y liquidada. Una parte de la jurisprudencia se inclinaba a favor de su subsistencia (SSTS núm. 979/2011, de 27 de diciembre, y núm. 220/2013, de 20 de marzo), frente al pronunciamiento —aislado- de la STS núm. 503/2012, de 25 de julio, en la que se sostuvo que la cancelación de asientos registrales es el momento determinante de la extinción social.

Así las cosas, y en línea con lo sostenido por la DGRN en sus Resoluciones de 14 de diciembre de 2016, de 13 y 20 de mayo de 1992, de 15 de febrero de 1999, de 14 de febrero de 2001, de 29 de abril de 2011 y de 17 de diciembre de 2012, esta importante STS del Pleno de la Sala 1. ${ }^{a}$ resuelve que, aunque la extinción y cancelación registral impide a la sociedad operar en el tráfico jurídico-económico, conserva su personalidad frente a reclamaciones de deudas sobrevenidas, a los efectos de que puedan integrarse en las operaciones de liquidación; de ahí que la sociedad disuelta y liquidada pueda ser parte demandada en estos procesos y su representación procesal se integre con la representación que ostenta el liquidador.

«Aunque la inscripción de la escritura de extinción y la cancelación de todos los asientos registrales de la sociedad extinguida conlleva, en principio, la pérdida de su personalidad jurídica, en cuanto que no puede operar en el mercado como tal, conserva esta personalidad respecto de reclamaciones pendientes basadas en pasivos sobrevenidos, que deberían haber formado parte de las operaciones de liquidación. A estos efectos, relacionados con la liquidación de la sociedad, esta sigue teniendo personalidad, y por ello capacidad para ser parte demandada. En otros términos, empleados por la Dirección General de los Registros y del Notariado, "después de la cancelación persiste todavía la personalidad jurídica de la sociedad extinguida como centro residual de imputación en tanto no se agoten totalmente las relaciones jurídicas de que la sociedad es titular" (Resolución de 14 de diciembre de 2016) [...] 
Es cierto que la actual Ley de Sociedades de Capital, en su art. 399, prevé la responsabilidad solidaria de los antiguos socios respecto de las deudas sociales no satisfechas hasta el límite de sus respectivas cuotas de liquidación, en caso de pasivos sobrevenidos. En muchos casos, para hacer efectiva esta responsabilidad, no será necesario dirigirse contra la sociedad. Pero reclamaciones como la presente, sin perjuicio de que acaben dirigiéndose frente a los socios para hacer efectiva responsabilidad solidaria hasta el límite de sus respectivas cuotas de liquidación, pueden requerir de un reconocimiento judicial del crédito, para lo cual resulte conveniente dirigir la demanda frente a la sociedad. En estos supuestos, en que la reclamación se basa en que el crédito reclamado debería haber formado parte de la liquidación, y que, por tanto, la practicada no es definitiva, no sólo no debemos negar la posibilidad de que pueda dirigirse la reclamación frente a la sociedad, sino que, además, no debemos exigir la previa anulación de la cancelación y la reapertura formal de la liquidación. De este modo, no debe privarse a los acreedores de la posibilidad de dirigirse directamente contra la sociedad, bajo la representación de su liquidador, para reclamar judicialmente el crédito, sobre todo cuando, en atención a la naturaleza del crédito, se precisa su previa declaración. Dicho de otro modo, a estos meros efectos de completar las operaciones de liquidación, está latente la personalidad de la sociedad, quien tendrá capacidad para ser parte como demandada, y podrá estar representada por la liquidadora, en cuanto que la reclamación guarda relación con labores de liquidación que se advierte están pendientes. Además, el art. 400 LSC atribuye esta representación a los (antiguos) liquidadores para la formalización de actos jurídicos en nombre de la sociedad, tras su cancelación. De ahí que ratifiquemos la posición contenida en las Sentencias de esta Sala de 979/2011, de 27 de diciembre, y 220/2013, de 20 de marzo, y entendamos que la sociedad demandada gozaba de capacidad para ser parte en este concreto pleito, en el que se reclama la reparación del perjuicio sufrido por un cumplimiento defectuoso de las obligaciones contractuales asumidas por la sociedad frente a la demandante».

STS (Sala 1. ${ }^{a}$ ) núm. 336/2017, de 29 de mayo (rec. 483/2015): inexistencia de responsabilidad civil del procurador por la caducidad de una anotación preventiva de embargo a causa de no tener obligación de cuidado

Presentada demanda de responsabilidad contra un procurador y su aseguradora por la caducidad de una anotación preventiva de embargo, la 
demanda fue desestimada en ambas instancias y ahora se acude en casación. Esta sentencia, que también desestima el recurso, aborda el contenido y el alcance de las obligaciones del procurador en todo proceso y repasa la jurisprudencia existente sobre la responsabilidad del procurador.

«Esta sala, en supuestos de hecho semejantes, ya se ha pronunciado en alguna ocasión y ha considerado que el obligado a instar la prórroga de la anotación preventiva de embargo es el abogado, y ha indicado que dicha prórroga no puede considerarse como mero acto de impulso procesal al tratarse de una actuación encaminada a asegurar la eficacia de medida cautelar para garantizar el buen fin del procedimiento [...]

La sentencia recurrida, por tanto, no sólo no se opone a la jurisprudencia de esta sala, sino que la conoce y asume. Obligación de los procuradores es representar a la parte en todo tipo de procesos, salvo que se disponga otra cosa o se autorice por Ley. Se trata de una obligación vinculada al seguimiento del juicio, transmisión de documentación, antecedentes o instrucciones que le remitan el abogado, tener al corriente a su poderdante y abogado del curso del asunto que se le hubiere confiado y hacer cuanto conduzca a la defensa de los intereses del cliente, bajo la responsabilidad que las leyes impongan al mandatario, conforme dispone el art. 26 de la LEC.

Ahora bien, la afirmación de que entra dentro de las competencias del procurador el cumplimento de obligaciones como la que aquí se suscita de solicitud de prórroga para evitar la caducidad preventiva del embargo, no se ajusta a esta normativa, por lo que la inactividad del procurador contra el que se dirige la demanda no genera incumplimiento contractual como integrante de una infracción del deber de diligencia profesional.

$Y$ es que, al margen del auxilio que el procurador pueda prestar en este aspecto al abogado, no es un acto de impulso procesal, como ha dicho esta sala, ni es un efecto de las funciones que tiene encomendadas de representación o de seguimiento del asunto. Se trata de una iniciativa propia del abogado en la defensa y dirección del proceso en cuanto supone una actuación de contenido jurídico-económico, y que es ajena a la capacidad de decisión del procurador, que no es otra que la de notificar, como argumenta la sentencia recurrida, "la existencia de un plazo procesal y el momento en que este comienza conforme a la notificación recibida o el acto por él realizado, pero no le corresponde un deber legal de velar porque ese plazo sea respetado adecuadamente por el abogado y, por ello, no tiene una función específica de avisar de la proximidad de su vencimiento. Es el abogado quien ha de conocer los plazos perentorios, como el que nos ocupa, y en función de ellos debe adoptar las decisiones técnicas corres- 
pondientes en consonancia con las instrucciones del cliente, sin que sea el procurador quien vele por el correcto cumplimiento de lo que es deber del abogado. Entenderlo de otro modo supone atribuir una función al procurador que le convertiría en auténtico controlador de los tiempos procesales que, evidentemente, trasciende a la misión que le atribuye la ley"».

\section{TRIBUNAL SUPREMO: SALA 2. ${ }^{a}$ O DE LO PENAL}

STS (Sala 2. ${ }^{\text {) }}$ núm. 28/2017, de 25 de enero (rec. 949/2016): ni se puede ni se debe aplicar la «tesis del tribunal» para condenar por un título penal aplicable a un relato histórico no equiparable al que fue objeto de acusación

La SAP de Madrid absolvió a la acusada del delito de apropiación del que venía acusada por haber realizado, contando con autorización, varias disposiciones bancarias de la cuenta de una anciana a la que cuidaba el día siguiente al de su fallecimiento. Contra la sentencia se interpone recurso de casación por - entre otros motivos- vulneración del derecho a la tutela judicial efectiva a causa de no haber corregido el tribunal los defectos de calificación de los hechos haciendo uso de la llamada tesis del tribunal del art. 733 LECRIM.

La Sala 2. ${ }^{a}$ del TS desestima el motivo porque, además de excepcional y potestativa, la facultad de la tesis no autoriza a modificar la base fáctica de la acusación, sino sólo la jurídica. En el caso, se absolvió del delito de apropiación indebida porque, con el fallecimiento de la anciana, se extinguió la facultad dispositiva de la acusada y, con ello, la posibilidad de cometer los hechos típicos de este delito. Y frente a la pretensión de que el tribunal introdujera la calificación del delito de estafa al amparo de la tesis, se opone a ello la Sala porque el engaño causado al banco consistente en omitir el fallecimiento de la titular para disponer del dinero no se encontraba en los escritos de acusación.

«Olvida el recurrente que tal posibilidad de propuesta es facultativa y de ejercicio, según la propia ley, excepcional, de la que el Tribunal usará con moderación.

Pero aún más, como dice el mismo precepto invocado, la propuesta se circunscribe a una eventual nueva calificación del hecho justiciable, pero sin que, por tanto, éste pueda ser modificado.

Tal precepto, conforme advierte la mejor doctrina procesalista, permite entender la diversidad de contenido y alcance entre las exigencias del prin- 
cipio acusatorio y el derecho de defensa. Éste está ínsito en el acusatorio, pero su ámbito de aplicación es más extenso. Cabe pues afectarse el derecho de defensa aunque no se vulnere el principio acusatorio.

Así, aun respetando la identidad sustancial del hecho objeto de acusación, la modificación del título jurídico de la condena puede acarrear vulneración del derecho de defensa porque ésta aconsejara articularse en el caso con una estrategia diversa, en lo que respecta a las tesis jurídicas, a la que el acusado no acude por falta de aviso de la eventual aplicación de ese otro título jurídico. De ahí que para tal condena el planteamiento de la tesis sea exigible. Porque el mismo abre un nuevo debate y correlativa posibilidad de acudir a otro título jurídico de condena.

Pero el principio acusatorio, también tributario del derecho de defensa, y de la imparcialidad del juzgador, priva a éste de la oficiosidad de una propuesta que implique una alteración sustancial del hecho tal como fue propuesto por las partes.

Y precisamente lo que ocurre en el caso juzgado es que la calificación de la acusación es diversa de la que el Tribunal entiende que correspondería. Y, además, la heterogeneidad entre los tipos penales de estafa y apropiación indebida obligaría a la defensa, para rebatir el delito de estafa no incluido en la acusación, a adoptar una defensa diversa.

Ciertamente, si la cuestión acabase en ello cabría plantearse la vía del art. 733 LECrim.

Ocurre que en realidad lo que el Tribunal considera es que el hecho que resulta de la prueba, no el hecho que es objeto de acusación, es el que, además de merecer diferente calificación, es un supuesto histórico no equiparable, por tener diversidad sustancial con el atribuido por las acusaciones.

Lo que vetaba el recurso a la facultad del art. 733 tantas veces invocado».

STS (Sala 2. ${ }^{a}$ ) núm. 93/2017, de 16 de febrero (rec. 617/2016): no pierde la imparcialidad el juez que enjuicia al mismo acusado en causas distintas

El demandante de amparo, antes del proceso penal del que trae causa el recurso de amparo, fue condenado por un delito de alzamiento de bienes por haber enajenado sus bienes a nombre de familiares con el fin de esquivar el pago de la deuda contraída por Roque con varias entidades financieras que le habían prestado dinero. En una segunda causa penal también por delito de alzamiento de bienes alega la vulneración del derecho al juez 
ordinario predeterminado por la ley por formar parte del órgano enjuiciador una magistrada que participó en la primera condena. El TS rechaza el motivo de recurso, porque «los hechos que se dirimían en el referido recurso de apelación y los que se examinan en la presente causa no son los mismos. Puede decirse que son dos episodios fácticos integrantes de una conducta de alzamiento de bienes, pero se trata de hechos distintos, tanto en sí mismos como con relación a los sujetos activos que los ejecutaron, e incluso también en lo que respecta a las víctimas de ambas conductas [...]

Por consiguiente, no puede admitirse que la magistrada a la que ahora se tilda de falta de imparcialidad actuara con ese déficit procesal que se le atribuye, ya que se limitó a enjuiciar un hecho distinto y con protagonistas diferentes en la parte activa y pasiva de la intervención. Es cierto que coincidía la persona del recurrente, sin embargo, el hecho de que haya sido juzgado previamente en otra causa por unos hechos distintos no significa que no pueda ser enjuiciado por un mismo magistrado en un hecho diferente».

STS (Sala 2. ${ }^{a}$ ) núm. 95/2017, de 16 de febrero (rec. 10574/16): improcedencia de acumular penas impuestas en otro Estado UE en los supuestos del art. 14.2 de la LO 7/2014 y su conformidad con la Decisión Marco 2208/675

Esta STS aborda una cuestión muy específica del proceso de ejecución penal: la acumulabilidad de penas impuestas en otros Estados UE, las excepciones que recoge la LO 7/2014, de 12 de noviembre, sobre intercambio de información de antecedentes penales y consideración de resoluciones judiciales penales en la Unión Europea, y su compatibilidad con la Decisión Marco de la UE 2008/675/JAI (DM 2008), de 24 de julio de 2008, relativa a la consideración de las resoluciones condenatorias entre los Estados miembros de la Unión Europea con motivo de un nuevo proceso penal.

El caso arranca en diciembre de 2004, antes de la entrada en vigor la LO 7/2014, cuando Bienvenido — que se encuentra cumpliendo condena por delitos relacionados con terrorismo- solicita, en ejecución de sentencia dictada en julio de 2011, la acumulación de una pena que le había sido impuesta por la Cour d'Assises de París en septiembre de 2009 por hechos ocurridos en 1986. El Auto de la Audiencia Nacional deniega — con un voto particular- la acumulación de la anterior condena francesa en virtud de las exenciones al reconocimiento automático previstas por motivos 
objetivos en el apartado 2 del art. 14 de la LO 7/2014 [«b) las sentencias de condena que se impongan en procesos posteriores seguidos en España por delitos cometidos antes de que se hubiera dictado sentencia de condena por los Tribunales del otro Estado miembro»], así como por motivos temporales, ya que quedan las condenas anteriores al 15 de agosto de 2010. Por su parte, el voto particular consideraba que la solicitud de acumulación hubiera sido procedente, de no haberse aprobado la Ley Orgánica 7/2014, con la simple aplicación directa de la DM 2008, y que las excepciones introducidas en la ley española de trasposición, elaboradas tras la expiración del plazo previsto para ello, ha producido el efecto perjudicial para el reo de privarle de un derecho hasta entonces reconocido y, al menos, debiera haberse elevado cuestión prejudicial comunitaria sobre la conformidad de la norma española.

Pues bien, esta extensísima STS sigue la tendencia apuntada en la STS (Sala 2. ${ }^{a}$ ) núm. 874/2014, de 27 de enero, dictada a raíz de la entrada en vigor de la Ley Orgánica 7/2014, de 12 de noviembre, en el sentido de fijar que «la norma interna no reconoce efectos a todas las condenas en el extranjero de manera ilimitada, sin atender a criterios objetivos ni temporales. Sino que, al contrario, limita los supuestos de condenas en el extranjero con efectos en España de dos maneras: atendiendo a criterios objetivos (art. 14.2), así como a un criterio temporal imperativo, referido a las condenas anteriores al 15 de agosto de 2010».

La posterior entrada en vigor de la Ley 7/2014 no es obstáculo para que el caso, pese a promoverse antes, sea resuelto conforme a ella: «En nuestra sentencia de Pleno (que venía referida a un supuesto de hecho en situación temporal semejante al que ahora contemplamos) analizábamos tanto la imposibilidad de aplicar la Decisión Marco con exclusión de la norma legal vigente a la fecha de la resolución judicial como la inoperatividad de una solución jurisprudencial que no se ajustaba al contexto normativo en el que había de ser aplicada».

La inaplicabilidad del reconocimiento mutuo de la sentencia penal francesa se encuentra amparada, a juicio del TS, por las «excepciones decimos, que se contienen en la propia Decisión Marco; cuyo alcance explicitamos, en tanto que acogidas en la Ley Orgánica 7/2014, cuya mera existencia determina el criterio hermenéutico que imposibilita ahora la interpretación conforme de la Decisión. Lo que obliga, cuando menos, a precisar la viabilidad de la exclusión de la ponderación de la sentencia de otro Estado miembro cuando el efecto pretendido sea la acumulación en los términos referidos. 
Así, en la Decisión Marco, además de la carencia de efectos sobre la ejecución de la condena anterior del otro Estado miembro prevista en el art. 3.3 y la inaplicación cuando conlleve interferencias en las condenas o en la ejecución de condenas anteriores del Estado donde se desarrolle el nuevo proceso, previstas en el art. 3.4, resulta relevante para la resolución de este supuesto la excepción contenida en el art. 3.5:

a) Si la infracción penal por la que se desarrolla el nuevo proceso se cometió antes de que la condena anterior se haya dictado o ejecutado por completo,

b) los apartados 1 y 2 (donde se establece el principio de equivalencia) no tendrán por efecto el de exigir a los Estados que apliquen su legislación nacional relativa a la imposición de sanciones,

c) si la aplicación de dichas normas a las condenas extranjeras limitara al órgano jurisdiccional al imponer una sanción en el nuevo proceso.

En todo caso, los términos en los que está redactado el precepto de la Decisión, incluso acudiendo a las distintas redacciones en las diversas lenguas oficiales de la Unión, participan de un cierto carácter genérico, que ha permitido a los distintos Estados llevar a cabo una incorporación singularizada, mediante una adaptación a los distintos sistemas que existen en la Unión en materia de ejecución de penas, con los institutos propios (y diversos entre sí) de cada ordenamiento.

En autos, la proyección de esta excepción acogida por la legislación interna española, art. 14.2.b) y c), al margen de la concreta redacción de su incorporación, sería: a) el nuevo proceso que se celebra en España, donde recae Sentencia de 17 de octubre de 2003 que condena al recurrente a diez años de privación de libertad, deriva de hechos correspondientes a 1980, anteriores, por tanto, a los que motivan la condena en Francia, de fecha 26 de mayo de 1997, ejecutada allí, antes de su extradición a España; c) de modo que su ponderación conllevaría que el tiempo máximo de cumplimiento en España, por las condenas impuestas en España, pasaran de treinta a veinte años; $b$ ) luego no es exigible la aplicación del principio de equivalencia, ni, por tanto, el contenido de los arts. 76 LEC y 988 LECrim».

La sentencia prosigue y se pronuncia sobre la innecesidad de elevar cuestión prejudicial comunitaria y sobre la inexistencia de toda expectativa de derecho a la acumulación, ya con la normativa comunitaria como sin ella, con arreglo a los actuales arts. 76 CP (o 70 CP de 1973) y 988 LECrim, que no han sido modificados por la Ley 7/2014, sino que, simplemente, no contemplan las sentencias extranjeras. 
«En definitiva, con la interpretación que ahora se mantiene el principio de interpretación conforme no da lugar a resultados incoherentes, porque la interpretación del Derecho en su conjunto arriba al principio de equivalencia con excepciones, autorizadas por la propia Decisión y ahora incorporadas a nuestro ordenamiento interno».

STS (Sala 2. ${ }^{a}$ ) núm. 116/2017, de 23 de febrero (rec. 1281/2016): condena por delito fiscal basada en datos provenientes de la «lista Falciani»: licitud del uso de la información financiera sustraída por un informático del banco, intervenida por las autoridades francesas y remitida a la AEAT mediante solicitud de cooperación internacional

Esta es la primera STS que aborda la licitud de usar en un proceso penal la información de la llamada lista Falciani, cuyo origen es notorio: el ingeniero informático Hervé Falciani, mientras fue empleado en Ginebra del banco HSBC entre los años 2001 y 2008, accedió y copió datos financieros de miles de clientes de la entidad y, por la pasividad de las autoridades suizas ante la evasión fiscal, huyó con los datos, primero, a España y, luego, a Francia, donde fueron incautados en un registro domiciliario. A principios del año 2010 las autoridades españolas solicitaron a las francesas cuanta información dispusieran en relación con los contribuyentes sujetos a la soberanía fiscal española que figurasen en el listado del banco suizo HSBC, y como respuesta a esta petición, la autoridad francesa puso a disposición de la AEAT la información de la que disponía en un CD-Rom que el agregado fiscal de la embajada francesa entregó personalmente a la autoridad española.

A raíz de esta información se formó un expediente tributario a Darío y, luego, una causa penal en la que ha resultado condenado como autor de dos delitos contra la hacienda pública por dejar de abonar más de dos millones de euros entre los ejercicios 2005 y 2006. Ahora recurre en casación denunciando la infracción de los derechos a la intimidad personal, a la tutela judicial efectiva, a la presunción de inocencia y a un proceso con todas las garantías, por haberse valorado como prueba de cargo una prueba ilícitamente obtenida, protegida por el secreto bancario y la intimidad personal, que no son los datos originarios del banco BSCH, pero que traen causa de ellos por ser información contenida en los equipos informáticos de Falciani extractada y tratada informáticamente por las autoridades fiscales francesas antes de ser remitida a las españolas, esto es, la llamada «lista Lagarde» o fichas BUP. 
Frente a los argumentos de la demanda dirigidos a denunciar la ilicitud de la prueba, la Sala 2. ${ }^{a}$ del TS sostiene su licitud en esta importante sentencia en la que se defiende la necesidad de dispensar un tratamiento singularizado a las pruebas obtenidas ilícitamente por particulares. La argumentación es prolija y muy rica, y comienza analizando el valor probatorio que en otros ordenamientos se da a documentos bancarios y ficheros contables sustraídos de forma ilegítima por un tercero, para terminar negando la aplicación, en el caso, del principio de exclusión de la prueba ilícitamente obtenida.

«La Sala estima que más allá de algunas precisiones que se limitan a matizar el rico y exhaustivo cuadro argumental expuesto por la Sección 23 de la Audiencia de Madrid, la validez de la prueba proporcionada por las autoridades francesas al fisco español puede sostenerse a partir del concepto mismo de prueba ilícita proclamado por nuestro sistema.

El poder del Estado para la persecución y enjuiciamiento de hechos ilícitos no puede valerse de atajos. El ejercicio de la función jurisdiccional sólo se ajusta al modelo constitucional cuando se asienta sobre los principios que definen el derecho a un proceso con todas las garantías. Estos principios, a los que no falta una verdadera dimensión ética, actúan como una fuente de limitación de la actividad estatal. La vulneración de derechos del acusado, ya sea mediante un acto de carácter delictivo, ya mediante la vulneración de sus derechos y libertades fundamentales, abre una grieta en la estructura misma del proceso penal. Sus efectos contaminantes alcanzan a otros actos procesales conectados a la antijuridicidad originaria y que pueden resultar afectados en su aparente validez.

En definitiva, está fuera de discusión la necesidad de excluir el valor probatorio de aquellas diligencias que vulneren el mandato prohibitivo del art. 11 LOPJ. Pero más allá del fecundo debate dogmático acerca de lo que se ha llamado la eficacia horizontal de los derechos fundamentales, es evidente que la acción vulneradora del agente de la autoridad que personifica el interés del Estado en el castigo de las infracciones criminales nunca puede ser artificialmente equiparada a la acción del particular que, sin vinculación alguna con el ejercicio del ius puniendi, se hace con documentos que más tarde se convierten en fuentes de prueba que llegan a resultar, por una u otra circunstancia, determinantes para la formulación del juicio de autoría. El particular que por propia iniciativa desborda el marco jurídico que define la legitimidad del acceso a datos bancarios, ya actúe con el propósito de lograr un provecho económico, ya con el de fomentar el debate sobre los límites del secreto bancario, no lo hace en 
nombre del Estado. No rebasa el cuadro de garantías que define los límites constitucionales al acopio estatal de fuentes de pruebas incriminatorias. Nada tiene que ver esa actuación con la de un agente al servicio del Estado. Lo que proscribe el art. 11 LOPJ no es otra cosa que la obtención de pruebas ("no surtirán efecto las pruebas obtenidas..."). Es el desarrollo de la actividad probatoria en el marco de un proceso penal —entendido éste en su acepción más flexible- lo que queda afectado por la regla de exclusión cuando se erosiona el contenido material de derechos o libertades fundamentales.

La necesidad de un tratamiento singularizado de la prueba obtenida por un particular cometiendo un delito o vulnerando derechos fundamentales no es, desde luego, una originalidad sugerida por la Sala [...]

Pues bien, la Sala entiende que la posibilidad de valoración de una fuente de prueba obtenida por un particular con absoluta desconexión de toda actividad estatal y ajena en su origen a la voluntad de prefabricar pruebas no necesita ser objeto de un enunciado legal que así lo proclame. Su valoración es perfectamente posible a la vista de la propia literalidad del vigente enunciado del art. 11 LOPJ y, sobre todo, en atención a la idea de que, en su origen histórico y en su sistematización jurisprudencial, la regla de exclusión sólo adquiere sentido como elemento de prevención frente a los excesos del Estado en la investigación del delito. Esta idea late en cuantas doctrinas han sido formuladas en las últimas décadas con el fin de restringir el automatismo de la regla de exclusión. Ya sea acudiendo a las excepciones de buena fe, de la fuente independiente o de la conexión atenuada, de lo que se trata es de huir de un entendimiento que, por su rigidez, aparte la regla de exclusión de su verdadero fundamento. La prohibición de valorar pruebas obtenidas con vulneración de derechos fundamentales cobra su genuino sentido como mecanismo de contención de los excesos policiales en la búsqueda de la verdad oculta en la comisión de cualquier delito. No persigue sobreproteger al delincuente que se ve encausado con el respaldo de pruebas que le han sido arrebatadas por un particular que cuando actuaba no pensaba directamente en prefabricar elementos de cargo utilizables en un proceso penal ulterior». 
STS (Sala 2. ${ }^{a}$ ) núm. 156/2017, de 13 de marzo (rec. 1304/2016): vulneración del derecho a la presunción de inocencia: improcedente condena basada en declaraciones sumariales de coacusados que se acogieron al derecho a no declarar contra sí mismos

Tras la celebración de juicio oral en cuyo inicio los coacusados, Rodolfo y Mauricio, desistieron de sus acusaciones recíprocas y se acogieron a su derecho a no declarar, la AP de Almería les condenó a un año de prisión como autores de un delito de lesiones, contra la que Mauricio interpone recurso de casación ex art. 5.4 LOPJ por vulneración del derecho a la presunción de inocencia del art. 24.2 CE, por no existir prueba de cargo suficiente y con las debidas garantías de la que pueda deducirse, racionalmente, su autoría en los hechos.

El TS compendia su doctrina sobre la presunción de inocencia; confirma la posibilidad de acudir a la lectura de las declaraciones instructorias del acusado al amparo del art. 714 LECrim cuando se acoge a su derecho a no declarar (pues un rígido entendimiento de este precepto «supondría de facto reconocer al acusado no sólo su derecho a no declarar, sino el derecho de excluir o borrar las declaraciones propias hechas voluntariamente en momentos anteriores»), y así llega hasta la validez, como prueba de cargo, de las declaraciones sumariales de los coacusados y los criterios que deben presidir su valoración.

En el caso examinado no procede valorar como prueba de cargo la declaración sumarial del coacusado en la que sostuvo que fue gratuitamente agredido por el recurrente, porque no se interesó su lectura ni se debatió en el sumario, ya que «el órgano de enjuiciamiento tampoco hace referencia a esa declaración para fundar su convicción, limitándose a argumentar la condena de Mauricio en tres elementos: 1) que los dos acusados se acogieron en el plenario a su derecho a no declarar; 2) que los testigos declararon no recordar con precisión lo ocurrido, en consideración al tiempo transcurrido, y 3) la postura procesal mantenida por los dos acusados, que al inicio de la vista oral renunciaron al ejercicio de la acusación particular que hasta entonces habían sostenido recíprocamente, decisión que los letrados justificaron en el hecho de haberse indemnizado mutuamente por los daños corporales que se infligieron el uno al otro, lo que el tribunal expresamente interpreta como un reconocimiento inequívoco de responsabilidad en cada una de las agresiones».

La verdad o falsedad de los hechos — dice el TS — no puede alcanzarse «empleando como método de prospección la concreta actuación proce- 
sal de las partes. El ejercicio de acciones penales, la opción por una mera reparación indemnizatoria o la renuncia a cualquier derecho que pueda derivarse de un ilícito penal, no es sino la manifestación del libre ejercicio de un derecho subjetivo amparado por el ordenamiento jurídico y que, por sí mismo, no permite presuponer o reforzar los indicios de responsabilidad criminal; como tampoco lo desvelan los planteamientos procesales que se puedan desarrollar por su asistencia técnica, que — desde la probidadestá únicamente sujeta a la mejor protección del interés del cliente y que lo hace desde la singular priorización de los distintos factores que pueden resultar de interés para su representado, los cuales no pueden ni deben ser evaluados desde una contemplación externa de la relación abogado-cliente.

Decae así que el tribunal pueda fundamentar racionalmente la realidad de la agresión en que el recurrente renunciara a ejercitar acciones penales; debiéndose destacar además que el abogado del recurrente nunca expresó que su cliente hubiera indemnizado a Rodolfo, limitándose a afirmar en el trámite de cuestiones previas — ante la interpelación planteada por el Ministerio Público - lo contrario, esto es, que su cliente: "Sí, ha sido debidamente indemnizado y no tiene nada que reclamar".

$\mathrm{Y}$ analizando el acervo probatorio utilizado en el juicio que ahora nos ocupa [...] no sólo decaería la credibilidad de la versión facilitada por Rodolfo en la fase sumarial, sino que puede concluirse que ninguna de las pruebas practicadas presta soporte a la actuación del recurrente que describe el factum de la sentencia».

Consecuentemente, se estima el recurso y se anula la condena impuesta al recurrente.

STS (Sala 2. ${ }^{\text {) }}$ núm. 226/2017, de 31 de marzo (rec. 1825/2016): recurso de casación contra auto de sobreseimiento libre dictado por la audiencia provincial en procedimiento abreviado pese a la interposición previa de recurso de súplica por error en la instrucción de los recursos

Alegada por las defensas la prescripción de los delitos en el turno de intervenciones previas del juicio oral del procedimiento abreviado, la AP la estima y dicta auto de sobreseimiento libre con claros errores en la instrucción de los recursos. En su versión inicial constaba la firmeza de la resolución, error que provocó que la acusación particular interpusiera recurso de reforma. Posteriormente el auto fue aclarado y se hizo constar que cabía recursos de súplica y/o casación, de modo que el de reforma interpuesto se 
admitió como recurso de súplica y fue resuelto por el auto contra el que se ha interpuesto ahora recurso de casación por infracción de forma.

Sobre la procedencia de este recurso dice la Sala 2. ${ }^{a}$ que «en realidad la resolución objeto de impugnación es la que acordó la prescripción y consecuente sobreseimiento libre en el trámite de cuestiones previas del art. 786.2 LECrim en un procedimiento cuya competencia para el enjuiciamiento venía atribuida a la Audiencia Provincial. Una resolución excluida del régimen general de recursos que el art. 236 LECrim diseña para los autos dictados por los tribunales de lo criminal, y que en equivalencia con el esquema de impugnación al que estaría sometida la sentencia que en su caso hubiera de dictarse sobre el fondo, es recurrible directamente en casación (art. 848 LECrim). Así lo ha admitido esta Sala (lo afirmaron expresamente, entre otras, las SSTS 1294/2011, de 21 de noviembre, o la 760/2014, de 20 noviembre), y las partes en este recurso no lo objetan.

En los casos en que es el órgano judicial al que compete la interpretación de la norma quien yerra en la indicación o advertencia de los recursos procedentes con la resolución de que se trate, el error en que a consecuencia de ello haya podido incurrir la parte ha de considerarse excusable, en cuanto que inducido por la autoridad que necesariamente ha de merecer la decisión judicial (otras SSTC 93/1983; 172/1985; 107/1987, de 25 de junio; 67/1994, de 28 de febrero; 65/2002. de 11 de marzo; 79/2004, de 5 de mayo; 241/2006, de 20 de julio; 30/2009, de 26 de enero; 55/2012, de 29 de marzo). De acuerdo con tal doctrina constitucional ha entendido esta Sala en supuestos en los que al recurso de casación había precedido el de súplica, que si bien ambos medios de impugnación son incompatibles por expresa dicción legal, si el recurrente atendió las indicaciones que sobre el régimen de recursos de la resolución le proporcionó el órgano jurisdiccional, la eventual causa de inadmisibilidad, sin perjuicio de dejar constancia de ella, ha de dejarse pasar por alto (SSTS 1079/2012, de 3 de enero de 2013; 740/2014, de 6 de noviembre, o 154/2015, de 17 de marzo)».

STS (Sala 2. ${ }^{a}$ ) núm. 287/2017, de 19 de abril (rec. 1893/2016): validez probatoria de fotografías de abusos sexuales de un padre a su hija facilitadas por la madre en una memoria flash procedentes de ordenador portátil de uso compartido

El proceso, que culminó con la condena del recurrente a penas —entre otras- de nueve y de cinco años de prisión por delito continuado de abuso 
sexual y de pornografía infantil, comenzó a raíz de la denuncia que la madre interpuso cuando casualmente encontró en el ordenador portátil del marido, que también era usado por otros miembros de la familia, material fotográfico que recogía abusos sexuales del padre sobre la hija entonces menor. La denunciante grabó los archivos fotográficos a una memoria flash y las entregó a la policía, que junto con la denunciante acudieron al domicilio, donde les estregó el ordenador portátil en cuestión. El padre alega haberse vulnerado sus derechos fundamentales a la intimidad y a la presunción de inocencia, por sostenerse la condena en prueba de cargo obtenida sin autorización judicial y con sospechas de manipulación. El TS desestima el recurso.

En cuanto al acceso al ordenador, el TS niega cualquier vulneración de derechos, porque carecía de disco duro y, por tanto, «ningún dato privado del acusado llegó a incorporarse a la causa». No obstante, «es evidente que la utilización de un ordenador por todos o varios de los miembros de una familia introduce una doble singularidad que merece ser destacada. De una parte, porque, con carácter general, el desafío probatorio que incumbe a la acusación a la hora de probar la autoría de un hecho ligado al empleo de las nuevas tecnologías exigirá siempre un esfuerzo argumental más depurado e intenso. Desde otra perspectiva, porque la reivindicación de una hipotética vulneración del derecho a la intimidad, en los supuestos de utilización compartida de un ordenador, no podrá prescindir de un hecho tan determinante como, por ejemplo, el uso común de una contraseña de acceso. Y es que, frente a lo que sucede respecto del contenido material de otros derechos, el derecho a la intimidad o, si se quiere, el espacio de exclusión que frente a otros protege el derecho al entorno virtual, es susceptible de ampliación o reducción por el propio titular. Quien incorpora fotografías o documentos digitales a un dispositivo de almacenamiento masivo compartido por varios es consciente de que la frontera que define los límites entre lo íntimo y lo susceptible de conocimiento por terceros, se difumina de forma inevitable [...]

Tampoco puede derivarse esa reivindicada ilicitud del hecho de que, en el momento de formalizar la denuncia contra Fidel, su esposa aportara una memoria flash en la que se contenían algunas de las imágenes expresivas de los actos lascivos ejecutados por el acusado sobre su hija. Quien así razona prescinde de dos ideas clave. De un lado, que esas imágenes están protagonizadas por la propia víctima, a la que el recurrente aproxima e introduce su pene entre los labios. Si una imagen queda afectada no es precisamente la del acusado, sino la de Tarsila, quien se ve obligada a proporcionar a los agentes una constancia gráfica de las sevicias a las que era sometida 
por su propio padre. De otra parte, ninguna objeción puede formularse al hecho de que quien aparece reflejado en esas imágenes, las incorpore a una memoria flash con el fin de ofrecer a los investigadores un respaldo probatorio de la realidad de los hechos denunciados [...]».

En cuanto a la posible quiebra de custodia, «la alegación de una quiebra de la cadena de custodia no puede convertirse en una recurrente estrategia para proyectar sobre una u otra pieza de convicción la duda de su integridad [...]

No basta con una reflexión genérica acerca de los riesgos potenciales de adulteración para desencadenar las dudas sobre su efectiva manipulación, con el consiguiente efecto en el ámbito del derecho a la presunción de inocencia. En estos casos, la defensa tiene a su alcance, no ya la posibilidad de proponer una prueba pericial alternativa al dictamen oficial de los expertos, sino la capacidad para designar un experto que se incorpore a las operaciones periciales acordadas por el juez de instrucción (cfr. art. 471 LECrim) [...]

Con independencia de ello, [las fotografías facilitadas en soporte flash] se trata de una prueba proporcionada por un particular a los agentes de la autoridad sin que esa entrega haya sido concebida como un mecanismo de elusión de las garantías que el sistema constitucional reconoce para la protección de los derechos a la intimidad y al entorno virtual».

STS (Sala 2. ${ }^{a}$ ) núm. 291/2017, de 24 de abril (rec. 1662/2016): criterios para la imposición de la condena en costas a la acusación particular en el supuesto de desistimiento de la acusación: concepto de temeridad y mala fe

En la fase de juicio oral del procedimiento abreviado seguido contra un policía local por delito de lesiones, la acusación particular mostró su voluntad de retirar la única acusación formulada contra el acusado y, en su consecuencia, la AP dictó sentencia absolutoria por ausencia de acusación y condenó a la acusación particular al pago de las costas del proceso. Contra esta sentencia recurre la acusación particular por infracción de lo dispuesto en los arts. 637 y ss. LECrim, en relación con lo dispuesto en el art. 782 LECrim.

En el recurso se argumenta que el desistimiento no fue sorpresivo ni abusivo, pues se presentó con anterioridad suficiente; en él se pedía el archivo de las actuaciones sin necesidad de celebrar juicio, y todo ello venía motivado por la imposibilidad de la acusadora de sufragar los gastos, 
incluidos los de desplazamiento desde Cádiz hasta Valencia, que el proceso le suponía.

La cuestión central es, como ya se planteó en la STS (Sala 2.") núm. 169/2016, de 2 de marzo, y se ha vuelto a plantear en la STS (Sala 2. ${ }^{a}$ ) núm. 212/2017, de 29 de marzo (rec. 1865/2016), los criterios para imponer al acusador no oficial las costas ocasionadas al acusado absuelto, tomando como referencia el art. 240 LECrim y las pautas que la jurisprudencia ha consolidado para su aplicación: «Dos son las características genéricas que cabe extraer: a) que el fundamento es precisamente la evitación de infundadas querellas o la imputación injustificada de hechos delictivos, y b) que, dada las consecuencias que cabe ocasionar al derecho constitucionalmente reconocido antes indicado, la línea general de viabilidad de la imposición ha de ser restrictiva.

El punto crucial viene a ser la precisión del criterio de temeridad y mala fe a los que remite el artículo antes citado».

Sobre estos conceptos de «temeridad» y «mala fe» se extiende la STS, refiriendo el primero «al modo objetivo de ejercer las acciones legales, adjetivando un desempeño que resulta claramente infundado respecto del que es su marco legal regulatorio», mientras que la mala fe «tiene un contenido subjetivo e intencional, cuya significación se alcanza desde la individualización — también subjetiva- de su opuesto [...]

En todo caso, ambas actitudes entrañan que la acusación particular — por desconocimiento, descuido o intención- perturba con su pretensión el normal desarrollo del proceso penal, reflejando el deseo de ponerlo al servicio de fines distintos de aquellos que justifican su existencia; razón por la que la jurisprudencia proclama que la temeridad y la mala fe han de ser notorias y evidentes (SSTS núm. 682/2006, de 25 de junio, o 419/2014, de 16 abril), afirmando la procedencia de mantener una interpretación restrictiva de estos términos legales (STS núm. 842/2009, de 7 de julio), de modo que la regla general será su no imposición (SSTS de 19 de septiembre de 2001, 8 de mayo de 2003 y 18 de febrero, 17 de mayo y 5 de julio, todas de 2004, entre otras muchas).

En nuestra Sentencia 169/2016, de 2 de marzo, destacábamos también una serie de presupuestos procesales que afectan a la decisión de imponer las costas al querellante o al actor civil. Además del sometimiento al principio de rogación, hemos proclamado que: 1) La prueba de la temeridad o mala fe corresponde a quien solicita la imposición de las costas (Sentencia del Tribunal Supremo núm. 419/2014, de 16 abril). 2) No es determinante al efecto que la acusación no oficial haya mantenido posiciones en el proce- 
so diversas, incluso contrapuestas, a la de la acusación oficial (STS 91/2006, de 30 de enero). 3) El Tribunal a quo ha de expresar las razones por las que aprecia la concurrencia de un comportamiento procesal irreflexivo y, por tanto, merecedor de la sanción económica implícita en la condena en costas (SSTS núm. 508/2014, de 9 junio, y núm. 720/2015, de 16 noviembre).

En relación con la justificación de la eventual decisión de condena, resulta también controvertida la trascendencia que pueden tener las decisiones jurisdiccionales que, a lo largo del procedimiento, controlan la admisibilidad de la pretensión [...] Por ello, la evaluación de la temeridad y mala fe, para la imposición de las costas, no sólo debe de hacerse desde la consideración de la pretensión y actuación de la parte, sino contemplando la perspectiva que proporciona su conjunción con las razones recogidas en las decisiones interlocutorias que la han dado curso procesal (STS 384/2008, de 19 junio ).

Proyectado lo expuesto al caso de autos, no puede apreciarse el ejercicio temerario que la sentencia de instancia proclama».

En contra del valor que la sentencia de instancia atribuye al resultado de la prueba médico forense sobre la causa más probable de la lesión de la víctima, que excluyó que la causa fuera un objeto cilíndrico como una porra, el TS atiende al hecho de que el «el informe objetiva unas lesiones - también recogidas en las fotografías existentes en la causa-, sin que se muestre que la verosimilitud de la versión de la acusada desvanezca ante la tesis enfrentada del acusado o ante la afirmación de su compañero de que vio al acusado salir corriendo llevando la porra colgada; máxime cuando esas fuentes de prueba (que no se han visto corregidas por ninguna prueba practicada en el plenario) llevaron a la acusación pública a informar que la tesis acusatoria era razonable, y a sustentar la decisión judicial de prosecución por los trámites del procedimiento abreviado y a decretar posteriormente la apertura de juicio oral».

\section{STS (Sala 2. ${ }^{a}$ ) núm. 329/2017, de 9 de mayo (rec. 10748/2016): prueba indiciaria condenatoria en tribunal del jurado}

Esta STS se centra en la suficiencia y la motivación de los indicios que sustentan la condena del recurrente por dos delitos de asesinato y uno de quebrantamiento de condena, valorados todos ellos por el colegio de jurados con el sostén que para la debida motivación de la sentencia presta el magistrado-presidente. 
En el presente caso, los indicios existentes son los siguientes: $1{ }^{\circ} \mathrm{El}$ acusado estaba muy molesto con su exesposa, por cuanto ésta había roto toda relación con él. 2. ${ }^{\circ}$ Este quebranto del matrimonio había originado varios episodios violentos provocados por el acusado y sufridos por su entonces pareja sentimental. $3 .^{\circ}$ Incluso, el acusado había sido condenado con anterioridad por quebrantamiento de la condena que por efecto de los acontecimientos anteriores se la había impuesto. $4 .^{\circ}$ El día de los hechos enjuiciados y a una hora coincidente con los mismos el vehículo del acusado fue visto transitar cerca del lugar donde estos ocurrieron $5 .{ }^{\circ}$ Un testigo, además familia directa del acusado, manifestó que éste le había dicho telefónicamente «estoy viendo a Belén con uno, le voy a matar; perdón a la familia». $6{ }^{\circ}$ El mismo testigo señala que al día siguiente el acusado le volvió a llamar pidiéndole que retirara el vehículo de donde él lo había dejado — cerca de donde se produjeron las muertes- - . $^{\circ}$ El condenado se procuró coartadas que resultaron ser falsas.

«Es obvio que nos encontramos con pruebas indirectas o indiciarias, también denominadas circunstanciales, pero no es menos cierto que poseen iguales posibilidades probatorias que las directas.

En cuanto a la prueba indiciaria, la STS 220/2015, de 9 de abril, recogía el contenido de la STC 128/2011, de 18 de julio, la cual, enlazando con ideas reiteradísimas, sintetiza la doctrina sobre la aptitud de la prueba indiciaria para constituirse en la actividad probatoria de cargo que sustenta una condena: "A falta de prueba directa de cargo, también la prueba indiciaria puede sustentar un pronunciamiento condenatorio, sin menoscabo del derecho a la presunción de inocencia, siempre que: 1) el hecho o los hechos bases (o indicios) han de estar plenamente probados; 2) los hechos constitutivos del delito deben deducirse precisamente de estos hechos bases completamente probados; 3 ) se pueda controlar la razonabilidad de la inferencia, para lo que es preciso, en primer lugar, que el órgano judicial exteriorice los hechos que están acreditados, o indicios, y, sobre todo, que explique el razonamiento o engarce lógico entre los hechos base y los hechos consecuencia; y, finalmente, que este razonamiento esté asentado en las reglas del criterio humano o en las reglas de la experiencia común o en una comprensión razonable de la realidad normalmente vivida y apreciada conforme a los criterios colectivos vigentes" (SSTC 300/2005, de 21 de noviembre, FJ 3; 111/2008, de 22 de septiembre, FJ 3, y 70/2010, FJ 3). Asumiendo "la radical falta de competencia de esta jurisdicción de amparo para la valoración de la actividad probatoria practicada en un proceso penal y para la evaluación de dicha valoración conforme a criterios 
de calidad o de oportunidad" (SSTC 137/2005, de 23 de mayo, FJ 2, y 111/2008, de 22 de septiembre, FJ 3), sólo se considera vulnerado el derecho a la presunción de inocencia en este ámbito de enjuiciamiento cuando "la inferencia sea ilógica o tan abierta que en su seno quepa tal pluralidad de conclusiones alternativas que ninguna de ellas pueda darse por probada" (SSTC 229/2003, de 18 de diciembre, FJ 4; 111/2008, de 22 de septiembre, FJ 3; 109/2009, de 11 de mayo, FJ 3; 70/2010, de 18 de octubre, FJ 3, y 25/2011, de 14 de marzo, FJ 8).

Por otro lado, ha de tenerse en cuenta que el análisis del significado de cada uno de los indicios no puede realizarse aislándolo de los demás y poniendo de manifiesto que, de esa forma considerados, pudieran admitir una explicación alternativa razonable. Por el contrario, puestos en relación entre sí, la conclusión del Tribunal deberá reputarse razonable cuando todos los indicios muestren un significado probatorio coincidente en un mismo sentido.

En efecto, no cabe analizar individualmente cada indicio, como hace el recurrido, sino que es la valoración conjunta e interrelacionada de todos los indicios lo que permite expresar el engarce lógico entre los hechos objetivos acreditados y el hecho consecuencia. No siendo cuestionables los primeros, sólo cabrá analizar, dentro del núcleo discursivo, la racionalidad y solidez de la inferencia, que vendrá determinada - como bien apuntó el TSJ_ por la lógica y cohesión, así como por la suficiencia y calidad concluyente de dichos datos probatorios, sin que la inferencia pueda calificarse de excesivamente abierta, débil o imprecisa.

Octavo. Conforme a la doctrina legal expuesta, y aunque es cierto, como alega el recurrente, que el hecho en cuestión no fue presenciado por persona alguna, ni tampoco fue encontrada el arma del crimen, ni vestigios físicos o biológicos que señalaran indubitadamente al autor, no cabe la menor duda de que la prueba señalada tiene la entidad suficiente como para destruir la vigencia del principio constitucional invocado.

Volviendo a las explicaciones del magistrado-presidente del Tribunal del Jurado, el que ha cumplido a la perfección con su deber de detallar la prueba de cargo que tuvo en consideración el jurado, se destaca que el acusado faltó a la verdad en su declaración, pues no es cierto que hubiese aparcado donde dijo que lo hizo, resultando por lo demás esclarecedor lo que dijo sobre sus intenciones a su sobrino, al que trató de convencer posteriormente para buscar una coartada. También destacan que mintió sobre el coche, por cuanto dijo que lo tenía su expresado sobrino cuando, en realidad, lo había aparcado tras la Comisaría, pretendiendo que aquél 
lo recogiese. No dijo la verdad tampoco cuando manifestó que pidió cita previa con su abogada y que alguien se la dio, pues es la propia profesional con quien quería entrevistarse quien niega la posibilidad de que así hubiese sido. Y aunque no es correcto juzgar la razón por la cual el acusado puede "recuperar" la memoria, es lo cierto que los indicios existentes nos llevan a concluir razonablemente que el acusado es la única persona con un móvil tan poderoso como el que la prueba puso de manifiesto, quien realizó los hechos».

\section{SELECCIÓN DE OTRAS RESOLUCIONES Y ACTOS EN MATERIA PROCESAL}

AAP Murcia (Secc. 2. ${ }^{a}$, constituida con el pleno de los magistrados del orden penal) de 9 de enero de 2017 (rec. 295/2016), sobre fijación de criterio común relativo al carácter jurisdiccional e indelegable de la decisión sobre la solicitud de trascripción de declaraciones sumariales grabadas en vídeo.

Acuerdo del Pleno no jurisdiccional de la Sala de lo Civil del Tribunal Supremo de fecha 27 de enero de 2017, sobre criterios de admisión de los recursos de casación y extraordinario por infracción procesal.

Acuerdo no jurisdiccional de unificación de criterios de magistrados pertenecientes a las Secciones Civil y Mercantil de la Audiencia Provincial de Madrid de fecha 14 de febrero de 2017.

Acuerdo de Pleno jurisdiccional civil de la Audiencia Provincial de Murcia de fecha 17 de febrero de 2017, para unificar criterios en las Secciones Civiles en relación con los procedimientos de ejecución hipotecaria en los que se discuta la validez de la cláusula de vencimiento anticipado.

RDGRN de 24 de marzo de 2017, por la que se revoca la calificación negativa del registrador que suspendió la inscripción de un decreto de adjudicación dictado en proceso de ejecución hipotecaria a causa de existir, según el título, ocupantes a los que no consta que se les hubiera notificado la transmisión de la finca ex art. 25 LAU: inoponibilidad, desde la Ley $4 / 2013$, de 4 de junio, del arrendamiento no inscrito frente a tercer adquirente.

Instrucción 1/2017, de 27 de marzo, de la Fiscalía General del Estado, sobre la actuación del fiscal para la protección de los derechos al honor, intimidad y propia imagen de menores de edad con discapacidad ante los medios de comunicación audiovisual. 
Acuerdo no jurisdiccional de magistrados de la Audiencia Provincial de A Coruña de 30 de marzo de 2017, sobre suspensión de recursos de apelación interpuestos en procesos de ejecución hipotecaria afectados por las cuestiones prejudiciales planteada por el TS.

Instrucción 2/2017, de 28 de abril, de la Fiscalía General del Estado, sobre procesos incoados a raíz de la deducción de testimonios de una causa principal.

Dictamen 1/2017, de 19 de mayo, de la fiscal de Sala de Cooperación Internacional, sobre el régimen legal aplicable debido a la no trasposición en plazo de la directiva de la orden europea de investigación y sobre el significado de la expresión «disposiciones correspondientes» que sustituye dicha directiva.

Acuerdo (2.20) de la Comisión Permanente del CGPJ de 25 de mayo de 2017, por el que se acuerda la especialización de 54 juzgados de primera instancia - uno por provincia en la península y uno en cada una de las principales islas de los archipiélagos canario y balear- para conocer de forma exclusiva y no excluyente de los litigios relacionados con las condiciones generales incluidas en contratos de financiación con garantías reales inmobiliarias cuyo prestatario sea una persona física. 